\title{
Relationship between Multiple Sclerosis-Associated IL2RA Risk Allele Variants and Circulating T Cell Phenotypes in Healthy Genotype-Selected Controls
}

\author{
Sophie Buhelt ${ }^{1, *}$, Helle Bach Søndergaard ${ }^{1}$, Annette Oturai ${ }^{1}$, Henrik Ullum ${ }^{2}$, \\ Marina Rode von Essen ${ }^{1}$ and Finn Sellebjerg ${ }^{1}$ (D) \\ 1 Danish Multiple Sclerosis Center, Department of Neurology, Copenhagen University Hospital, \\ Rigshospitalet, 2600 Glostrup, Denmark; hbs@rh.dk (H.B.S.); abo@rh.dk (A.O.); \\ marina.rode.von.essen@regionh.dk (M.R.v.E.); finn.thorup.sellebjerg@regionh.dk (F.S.) \\ 2 Department of Clinical Immunology, Center of Clinical Investigation, Copenhagen University Hospital, \\ Rigshospitalet, 2100 Copenhagen, Denmark; Henrik.Ullum@regionh.dk \\ * Correspondence: sophie.buhelt.01@regionh.dk; Tel.: +45-3863-3334
}

Received: 29 May 2019; Accepted: 24 June 2019; Published: 25 June 2019

check for updates

\begin{abstract}
Single nucleotide polymorphisms (SNPs) in or near the IL2RA gene, that encodes the interleukin-2 (IL-2) receptor $\alpha$ (CD25), are associated with increased risk of immune-mediated diseases including multiple sclerosis (MS). We investigated how the MS-associated IL2RA SNPs rs2104286 and rs11256593 are associated with CD25 expression on T cells ex vivo by multiparameter flow cytometry in paired genotype-selected healthy controls. We observed that MS-associated IL2RA SNPs rs2104286 and rs11256593 are associated with expression of CD25 in CD4 ${ }^{+}$but not CD8 ${ }^{+} \mathrm{T}$ cells. In CD4 ${ }^{+} \mathrm{T}$ cells, carriers of the risk genotype had a reduced frequency of CD25 $5^{+} \mathrm{T}_{\mathrm{FH}} 1$ cells $(p=0.001)$ and an increased frequency of $\mathrm{CD}^{2} 5^{+}$recent thymic emigrant cells $(p=0.006)$. Furthermore, carriers of the risk genotype had a reduced surface expression of CD25 in post-thymic expanded CD4 ${ }^{+} \mathrm{T}$ cells $\left(\mathrm{CD}^{-} 1^{-} \mathrm{CD} 45 \mathrm{RA}^{+}\right), \mathrm{CD}^{+}{ }^{+} \mathrm{T}_{\mathrm{Reg}}$ cells and in several non-follicular memory subsets. Our study found novel associations of MS-associated IL2RA SNPs on expression of CD25 in CD4 ${ }^{+}$T cell subsets. Insight into the associations of MS-associated IL2RA SNPs, as these new findings provide, offers a better understanding of CD25 variation in the immune system and can lead to new insights into how MS-associated SNPs contribute to development of MS.
\end{abstract}

Keywords: IL2RA; CD25; multiple sclerosis; rs2104286; rs11256593; interleukin-2 receptor

\section{Introduction}

The cytokine interleukin-2 (IL-2) has an extensive array of effects that are central for the balance between immune tolerance and immunity [1,2]. The IL-2 receptor $\alpha$ chain (IL-2R $\alpha$ ), also known as CD25, specifically binds IL-2 and is a central component in the trimeric IL-2 receptor complex $[1,3]$. CD25 has a short cytoplasmic domain and is not involved in the downstream signal transduction [4]; instead CD25 delivers IL-2 to IL-2R $\beta$ and $\gamma c$ in a stepwise assembly [5,6] and creates a high-affinity receptor complex for the low levels of IL-2 in vivo [3]. Responsiveness to IL-2 directly depends on the cell's expression of CD25 as IL-2 signaling increases with its expression and correlates with the capacity to bind IL-2 in a stable IL-2/IL-2R complex $[7,8]$.

Among $\mathrm{T}$ cells, there is heterogeneity in CD25 expression $[7,8]$, with some $\mathrm{T}$ cells such as $\mathrm{T}$ regulatory $\left(\mathrm{T}_{\mathrm{Reg}}\right.$ ) cells constitutively expressing high levels [2,9]. However, on most cells expression of CD25 is inducible by $\mathrm{T}$ cell receptor activation and cytokine signals [3,7], including a positive IL-2 feed-back loop [10]. Heterogeneity in CD25 expression implies variability in the T cell's ability to 
benefit from the shared pool of IL-2, resulting in a tug of war with T cells with the highest expression of CD25 as winners [8,11].

IL-2 signaling is important for the survival and suppressive capacity of $\mathrm{T}_{\text {Reg }}$ cells [1]. In addition, IL-2 modulates polarization of effector functions by inducing IFN- $\gamma$ as well as receptors and transcription factors associated with a T helper $1\left(\mathrm{~T}_{\mathrm{H}} 1\right)$ committed lineage $[12,13]$, and expression of CD25 is required for the optimal development of $\mathrm{T}_{\mathrm{H}} 1$ cells [14]. IL-2 is also crucial for the expression of GM-CSF in human $\mathrm{T}$ cells [15]. Conversely, expression of receptors and transcriptions factors associated with $\mathrm{T}_{\mathrm{H}} 17$ lineage commitment is inhibited by IL-2 signaling [12,13]. In a competing environment, $\mathrm{T}_{\text {Reg }}$ cells augment $\mathrm{T}_{\mathrm{H}} 17$ differentiation, possibly by depletion of IL-2 [16,17]. Additionally, decreased IL-2 signaling increases the differentiation of $\mathrm{T}$ follicular helper $\left(\mathrm{T}_{\mathrm{FH}}\right)$ cells $[18,19]$, a CD4 ${ }^{+} \mathrm{T}$ cell subset able to provide specialized B cell help [20].

In $\mathrm{CD}^{+} \mathrm{T}$ cells, IL-2 signaling impacts the T cell's fate decision between memory and effector differentiation [1]. Cells receiving prolonged and strong IL-2 signaling by maintaining high CD25 expression expand rapidly, show enhanced effector functions, and are driven towards a terminally differentiated cell fate and apoptosis $[7,21,22]$. Conversely, cells receiving less IL-2 signaling are not cytolytic and differentiate into long-lived functional memory cells associated with a central memory phenotype [7,22-24]. However, transient high-affinity IL-2 receptor signaling early after priming promotes development of highly functional effector memory cells that later give rise to long-lived central memory cells [25]. Furthermore, high-affinity IL-2 signaling is required for the ability of memory $\mathrm{T}$ cells to expand in a competing environment with other $\mathrm{T}$ cells and induce a potent secondary expansion [23,24].

Single nucleotide polymorphisms (SNPs) in or near the IL2RA gene, that encodes CD25, have been associated with increased risk of several immune-mediated diseases [26-30]—including multiple sclerosis (MS). MS is a common demyelinating neurological disease triggered by environmental factors in individuals with a complex genetic risk profile [31,32]. The pathogenesis of MS involves dysregulated $\mathrm{T}_{\text {Reg }}$ cells [33-36], increased $\mathrm{T}_{\mathrm{FH}}$ activity [37], recruitment of proinflammatory $\mathrm{CD}^{+} \mathrm{T}$ cells to the CNS [31], accumulation of $\mathrm{CD}^{+} \mathrm{T}$ cells in CNS lesions [38], and increased concentration of soluble CD25 in sera [39].

The SNPs rs2104286 and rs11256593 in or near the IL2RA gene are associated with increased risk of developing MS [28-30]. The association between the SNP rs11256593 near the IL2RA gene and risk of MS has only recently been established in the MS replication chip study [29]. Previous studies of the MS-associated IL2RA SNP rs2104286 effects on immune cells have focused on a limited number of $\mathrm{CD}^{+} \mathrm{T}$ cell phenotypes. Carriers of the risk allele (T) for SNP rs2104286 were reported to have reduced IL-2 receptor signaling as measured by STAT5 phosphorylation [40], increased frequency of GM-CSF producing memory $\mathrm{CD} 4^{+} \mathrm{T}$ cells [15], increased frequency of $\mathrm{CD} 25^{+}$naïve $\mathrm{T}$ cells [41], and increased concentration of soluble CD25 [42]. Furthermore, studies in cell line models for helper and regulatory $\mathrm{T}$ cells have found that rs 2104286 polymorphisms influence the activity of enhancer elements from the first intron in the IL2RA gene and the binding affinity of the transcription factor TFAP4 $[43,44]$.

We aimed to investigate how CD25 expression is associated with MS-associated SNPs rs2104286 and rs 11256593 in or near the IL2RA gene in human $\mathrm{CD} 4^{+}$and $\mathrm{CD} 8^{+} \mathrm{T}$ cell subsets ex vivo. We analyzed this in freshly isolated peripheral blood mononuclear cells (PBMC) from genotype-selected healthy controls by multiparameter flow cytometry using a paired experimental design allowing for the quantitative assessment of $\mathrm{CD} 25$ expression on a wide range of $\mathrm{T}$ cell subtypes. We confirm that homozygous carriers of the MS-associated IL2RA risk alleles have an increased frequency of CD25 $5^{+}$ naïve $\mathrm{CD} 4^{+} \mathrm{T}$ cells and find that this difference is mainly observed in recent thymic emigrant cells. In addition, we report that homozygous carriers of the MS-associated IL2RA risk alleles have reduced $\mathrm{CD} 25$ expression on a wide range of memory $\mathrm{CD} 4{ }^{+} \mathrm{T}$ cells and decreased frequency of $\mathrm{CD} 25^{+} \mathrm{T}_{\mathrm{FH}} 1$ cells. 


\section{Material and Methods}

\subsection{Study Participants}

Study participants were recruited among 1000 healthy subjects in the Danish Blood Donor Cohort [45] who previously donated blood to the Danish Multiple Sclerosis Centers' (DMSC) contribution to the International Multiple Sclerosis Genetics Consortium (IMSGC) replication chip study [29]. The study was conducted in accordance with the Declaration of Helsinki and the protocol was approved by the scientific Ethics Committee in the Capital Region of Denmark (H-15008896). All participants gave written informed consent for inclusion before they participated in the study. Participants were selected based on a comprehensive lifestyle questionnaire (translated from Swedish and used with permission from Karolinska Institute, Sweden) [46] and the SNPs rs2104286 and rs11256593. SNP rs11256593 is the strongest associated SNP in the IL2RA gene region and in linkage disequilibrium (LD) with the previously associated lead SNP rs2104286 [29].

Selected study participants were recruited using a paired study design where each pair consisted of a homozygous carrier of the risk allele (T) for both MS associated IL2RA SNPs rs11256593 and rs2104286, defined as the risk genotype, and a homozygous carrier of the protective allele (C) of both SNPs, defined as a protective genotype. In addition, each pair was of the same sex and had a maximum age difference of 5 years. All participants were of self-reported European ancestry in two generations and not regular smokers for one year prior to inclusion. They reported no family history of MS and did not have any known autoimmune diseases (including type 1 diabetes, rheumatoid arthritis, inflammatory bowel disease, thyroid disease, or systemic lupus erythematosus). Furthermore, pregnant healthy subjects and healthy subjects with previous cancer were not recruited. Study participants had no self-reported intake of systemic anti-inflammatory, immunosuppressive, or immunomodulatory medications.

By recruiting 25 pairs, each pair consisting of a homozygous carrier of the risk genotype and a homozygous carrier of the protective genotype, we had $80 \%$ power to detect a standardized difference of 0.55 between subjects carrying the protective and risk genotype in a paired comparison. In a previous study we found that the association of the IL2RA SNP rs2104286 on the plasma concentration of soluble CD25 showed a standardized difference of 1.5 [47]. By including 25 genotype matched pairs we had sufficient statistical power to detect IL2RA SNP associations less than $40 \%$ of the magnitude of the known association with soluble CD25 concentrations.

\subsection{Genotyping}

Genotyping was performed on Illumina's MS replication custom bead chip and conducted by the International MS Genetics Consortium (IMSGC) [29].

\subsection{Sample Collection and PBMC Isolation}

Blood sampling and experimental procedures for each pair were performed on freshly prepared samples on the day of sample collection. Venous blood was collected in BD Vacutainer EDTA tubes (BD Bioscience, Plymouth, UK) from 1-2 fasting pairs between 7-9 a.m. Within $1 \mathrm{~h}$ the blood was diluted with phosphate buffered saline (PBS) (Life Technologies, Paisley, UK) containing 2mM EDTA (Thermo Fisher Scientific Baltics, Vilnius, Lithuania) and transferred to Leucosep tubes (Greiner Bio One; Frickenhausen, Germany), and the peripheral blood mononuclear cells (PBMCs) were isolated by density gradient centrifugation on Lymphoprep (Axis-Shield, Oslo, Norway). PBMCs were washed twice in PBS/EDTA.

\subsection{Flow Cytometry Analysis}

The flow cytometric analysis was performed on freshly isolated PBMC as a previous study showed that CD25 expression is affected by freeze-thaw procedures [41]. PBMCs were stained with fluorochrome-conjugated antibodies to identify blood $\mathrm{CD}^{+}$and $\mathrm{CD} 8^{+} \mathrm{T}$ cell subsets by flow cytometry. The staining procedure was conducted blinded to genotype and performed simultaneously for each 
pair. Prior to staining, FcR Blocking Reagent (Miltenyi Biotec, Bergisch Gladbach, Germany) was added to the PBMCs to prevent non-specific binding. We used the following monoclonal antibodies specific for: CD3 (PerCP/Cy5.5; UCHT1), CD3 (PE/Cy7; UCHT1), CD4 (APC/AF750; S3.5), CD8 (BV605; RPA-T8), CD25(PE; M-A251), CD127(BV421; A019D5), CD31 (BV605;WM59); CD39 (APC; A1); CD45RA (FITC;HI100), CXCR5 (APC;J252D4), PD-1 (BV605;EH12.2H7), CXCR3 (AF488;G025H7), CCR6 (PerCP/Cy5.5;G034E3), and CCR7 (AF647; G043H7). All antibodies were purchased from BioLegend (San Diego, CA, USA). The stained PBMCs were washed 3 times in cold PBS $/ 2 \% \mathrm{FCS} / 0.1 \%$ $\mathrm{NaN}_{3}$ and data were acquired on a FACS Canto II 8 color flow cytometer (BD Biosciences, San Jose, CA, USA) aiming for 350,000 acquisitions.

\subsection{Gating Strategy}

Data analysis was performed blinded to genotype status using FlowJo software (Tree Star, Ashland, OR, USA). Gating strategies are shown in Figures 1, 3, 4 and 6. Matched isotype controls were applied where appropriate. Median fluorescence intensity (MFI) was used as a measure for surface expression of CD25 on CD25 $5^{+}$cells (Figure 3D,E). Samples with a sub-optimal staining were excluded pair-wise before unblinding of genotype status. Thereby, we excluded 2 pairs that had poor staining of CD45RA; 3 pairs with poor staining of CD39 and CD31; 4 pairs with no usable sample for CD39/CD31.

\subsection{Statistical Analysis}

Statistical analysis was conducted with IBM SPSS Statistics 22 and GraphPad Prism 7. Normal distribution was determined by a Shapiro-Wilk test. Depending on normal distribution, all statistical analyses regarding genotype-phenotype associations were performed using a paired-sample t-test or a Wilcoxon Signed Rank test of samples collected the same day from matched pairs carrying either the risk or protective $I L 2 R A$ alleles. The significance level was set at $p \leq 0.005$ and $p$-values $\leq 0.05$ were considered suggestive in accordance with recent recommendations [48].

\section{Results}

To identify genotype-phenotype associations between MS-associated gene variants in the IL2RA gene and changes in CD25 expression in T cells, healthy study participants were recruited based on genotype status for the MS associated IL2RA SNPs rs2104286 and rs11256593 and lifestyle information from a large cohort of healthy blood donors. Only healthy subjects were recruited as previous studies have suggested that immunological alterations in established MS may compromise the ability to demonstrate the biological associations of SNPs associated with MS risk [39,47]. Recruited participants were either homozygous carriers of the risk alleles (T) for both SNPs rs2104286 and rs11256593, defined as a risk genotype (TT) or homozygous carriers of the protective alleles (C) for both SNPs, defined as a protective genotype (CC). Two-hundred subjects met our recruitment criteria and were contacted. Approximately 100 responded and in total we recruited 50 healthy subjects who were paired with respect to sex, age and genotype status for experimental procedures and statistical analysis of 25 pairs (Table 1).

Table 1. Demographic characteristics for the 50 healthy subjects included in the study. A risk genotype (TT) is defined as a homozygous carrier of the risk allele (T) for both MS-associated IL2RA SNPs rs2104286 and rs11256593. A protective genotype (CC) is defined as a homozygous carrier of the protective allele (C) for both MS-associated IL2RA SNPs rs2104286 and rs11256593.

\begin{tabular}{ccc}
\hline & Risk Genotype Group & Protective Genotype Group \\
\cline { 2 - 3 } & (TT) & (CC) \\
\hline $\mathrm{N}$ & 25 & 25 \\
Mean age (yr) & 46.7 & 47.0 \\
Age range (yr) & $24-68$ & $24-70$ \\
Male:female ratio & $9: 16$ & $9: 16$ \\
\hline
\end{tabular}




\subsection{Expression of CD25 on Nä̈ve and Memory $C D 4^{+} T$ Cell Populations}

CD45RA and CCR7 expression were used to delineate $\mathrm{CD} 4^{+}$and $\mathrm{CD} 8^{+} \mathrm{T}$ cell differentiation [49]. In both $\mathrm{CD}^{+}$and $\mathrm{CD}^{+}{ }^{+} \mathrm{T}$ cells, we observed a subpopulation with an intermediate expression of CD45RA and by the use of isotype control we found that it was not CD45RA ${ }^{-}$-a phenotypic characteristic associated with memory cells [49]. Thus, by differential expression of CD45RA and CCR7 we defined six subsets on $\mathrm{CD} 4^{+}$(Figure $1 \mathrm{~B}$ ) and $\mathrm{CD} 8^{+} \mathrm{T}$ cells (Figure $\left.1 \mathrm{H}\right)$ : Naïve $\left(\mathrm{CD} 45 \mathrm{RA}^{\text {hi }} \mathrm{CCR} 7^{+}\right.$); transitional central memory (T-CM) $\left(\mathrm{CD} 45 \mathrm{RA}^{\text {lo-int }} \mathrm{CCR} 7^{+}\right)$; central memory $(\mathrm{CM})\left(\mathrm{CD} 45 \mathrm{RA}^{-} \mathrm{CCR} 7^{+}\right)$; effector memory (EM) $\left(\mathrm{CD}^{2} 5 \mathrm{RA}^{-} \mathrm{CCR7}^{-}\right)$; late-EM (L-EM) $\left(\mathrm{CD}^{2} 5 \mathrm{RA}^{\text {lo-int }} \mathrm{CCR}^{-}\right)$, and terminally differentiated effector memory cells $\left(\mathrm{T}_{\mathrm{EMRA}}\right)\left(\mathrm{CD} 45 \mathrm{RA}{ }^{\text {hi }} \mathrm{CCR} 7^{-}\right)$.

On CD4 ${ }^{+} \mathrm{T}$ cells, expression of CD25 and the IL-7 receptor $\alpha$ (CD127) identify two CD25 ${ }^{+} \mathrm{CD} 4^{+} \mathrm{T}$ cell populations: The non-regulatory $\mathrm{CD} 127^{+} \mathrm{CD} 25^{+}$population and the regulatory $\mathrm{CD} 127^{\mathrm{lo}} \mathrm{CD} 25^{\mathrm{hi}}$ ( $\mathrm{T}_{\text {Reg }}$ ) population [50,51] (Figure 1D). The $\mathrm{CD} 127^{+} \mathrm{CD} 25^{+}$gate was applied to each of the six CD45RA/CCR7 subsets and we found that the highest frequency of $\mathrm{CD} 127^{+} \mathrm{CD} 25^{+}$cells was in the T-CM, CM, and EM CD4 ${ }^{+} \mathrm{T}$ cell populations (Figure 1F). Carriers of the risk genotype (TT) had a suggestively higher frequency of $\mathrm{CD} 127^{+} \mathrm{CD} 25^{+}$cells in naïve $(p=0.02)$ and T-CM $(p=0.02)$ populations compared to carriers of the protective genotype (CC) (Figure 2A). Conversely, carriers of the risk genotype (TT) had a suggestively reduced surface expression (MFI) of CD25 on CD127 ${ }^{+} \mathrm{CD} 25^{+}$ $\mathrm{T}$ cells in the T-CM $(p=0.02) ; \mathrm{CM}(p=0.03)$; $\mathrm{EM}(p=0.03)$, and L-EM $(p=0.05)$ populations (Figure $2 \mathrm{~B})$. $\mathrm{CD} 127^{+} \mathrm{CD} 25^{+} \mathrm{T}_{\mathrm{EMRA}}$ cells only represent $0.018 \%$ (IQR: $0.008: 0.008-0.026 \%$ ) of $\mathrm{CD} 4^{+} \mathrm{T}$ cells why these cells were excluded from statistical analysis. 

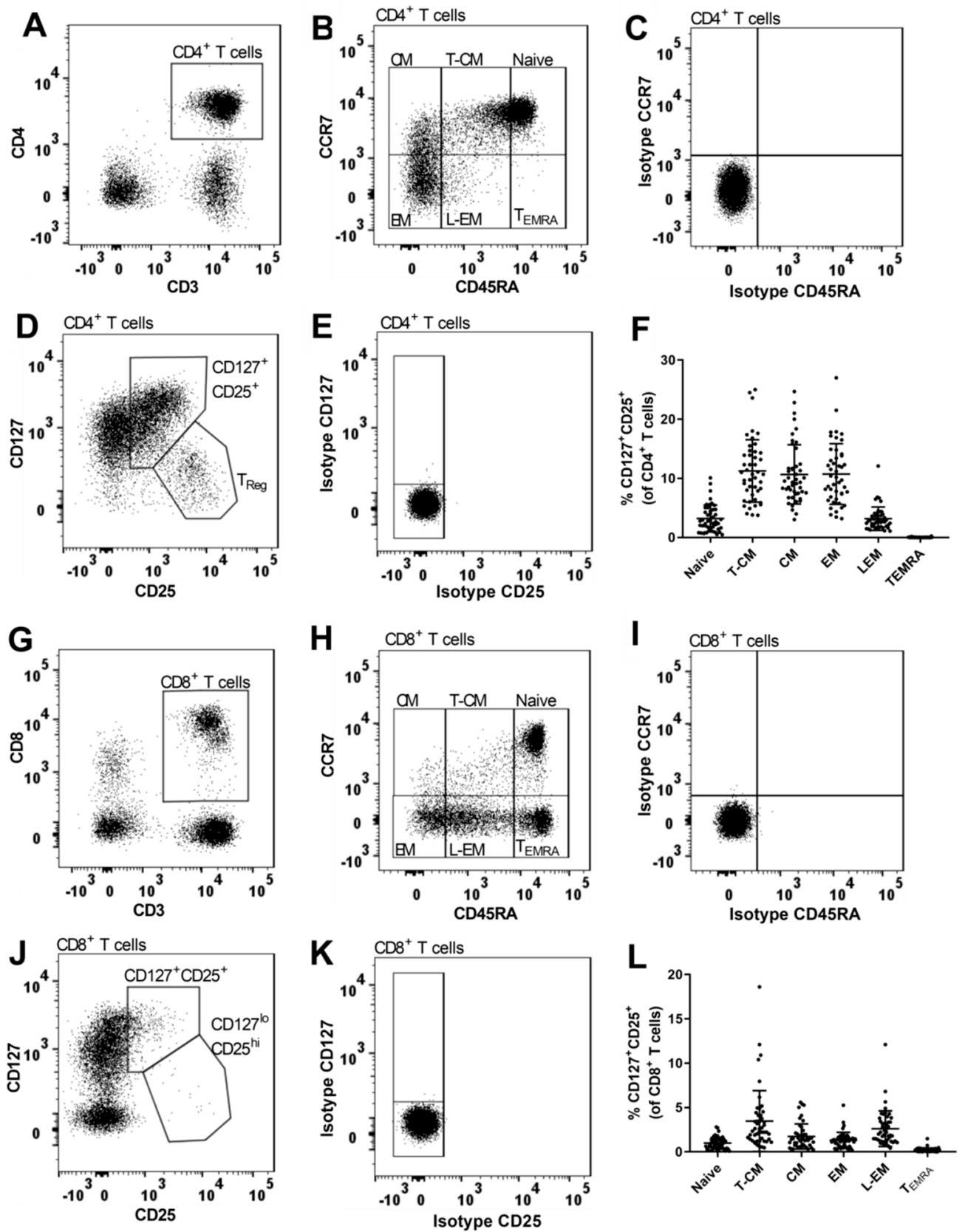

Figure 1. Gating strategy for $\mathrm{CD} 4^{+}$and $\mathrm{CD} 8^{+} \mathrm{T}$ cell differentiation. (A,G) Gating of $\mathrm{CD} 4^{+}$and $\mathrm{CD} 8^{+}$ T cells. (B,H) Differential expression of CD45RA and CCR7 defines 6 subsets on CD4 ${ }^{+}$and CD8 ${ }^{+} \mathrm{T}$ cells: Naïve $\left(\mathrm{CD} 45 \mathrm{RA}{ }^{\text {hi }} \mathrm{CCR7}{ }^{+}\right)$, transitional central memory $(\mathrm{T}-\mathrm{CM})\left(\mathrm{CD} 45 \mathrm{RA}{ }^{\text {lo-int }}{ }^{\mathrm{C} C R 7^{+}}\right)$, central memory (CM) $\left(\mathrm{CD}^{2} 5 \mathrm{RA}^{-} \mathrm{CCR} 7^{+}\right)$, effector memory (EM) $\left(\mathrm{CD}^{2} 5 \mathrm{RA}^{-} \mathrm{CCR} 7^{-}\right)$, late effector memory

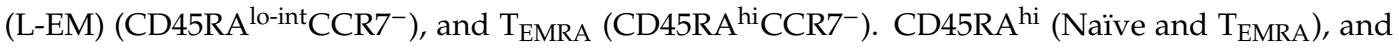
CD45RA ${ }^{\text {lo-int }}\left(\mathrm{T}-\mathrm{CM}\right.$ and L-EM) were gated on $\mathrm{CD} 8^{+} \mathrm{T}$ cells $(\mathrm{H})$ and subsequently applied to $\mathrm{CD} 4^{+} \mathrm{T}$ cells (B). $\mathrm{CCR7}^{+/-}$and CD45RA ${ }^{-}$(CM and EM) were gated by use of matched isotype control. (C,I) Matched isotype controls for CCR7 and CD45RA on CD4 ${ }^{+}$and CD8 ${ }^{+}$T cells. $(D, J)$ Differential expression of CD25 and CD127 defines two CD25 $5^{+}$populations on $\mathrm{CD}^{+}$and $\mathrm{CD} 8^{+} \mathrm{T}$ cells: $\mathrm{CD} 127^{+} \mathrm{CD} 25^{+}$cells and $\mathrm{T}_{\text {Reg }}\left(\mathrm{CD} 127^{\mathrm{lo}} \mathrm{CD} 25^{\mathrm{hi}}\right.$ ) cells. (E,K) Matched isotype controls for CD25 and CD127 on CD4 ${ }^{+}$and CD8 ${ }^{+} \mathrm{T}$ cells. (F) The $\mathrm{CD} 127^{+} \mathrm{CD} 25^{+}$gate is applied to the six $\mathrm{CD} 4^{+} \mathrm{T}$ cell subsets. Frequency of $\mathrm{CD} 127^{+} \mathrm{CD} 25^{+}$

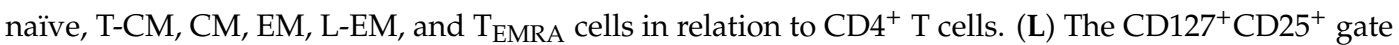
is applied to the six $\mathrm{CD}^{+} \mathrm{T}$ cell subsets. Frequency of $\mathrm{CD} 127^{+} \mathrm{CD} 25^{+}$naïve, T-CM, CM, EM, L-EM, and $\mathrm{T}_{\mathrm{EMRA}}$ cells in relation to $\mathrm{CD} 8^{+} \mathrm{T}$ cells. 

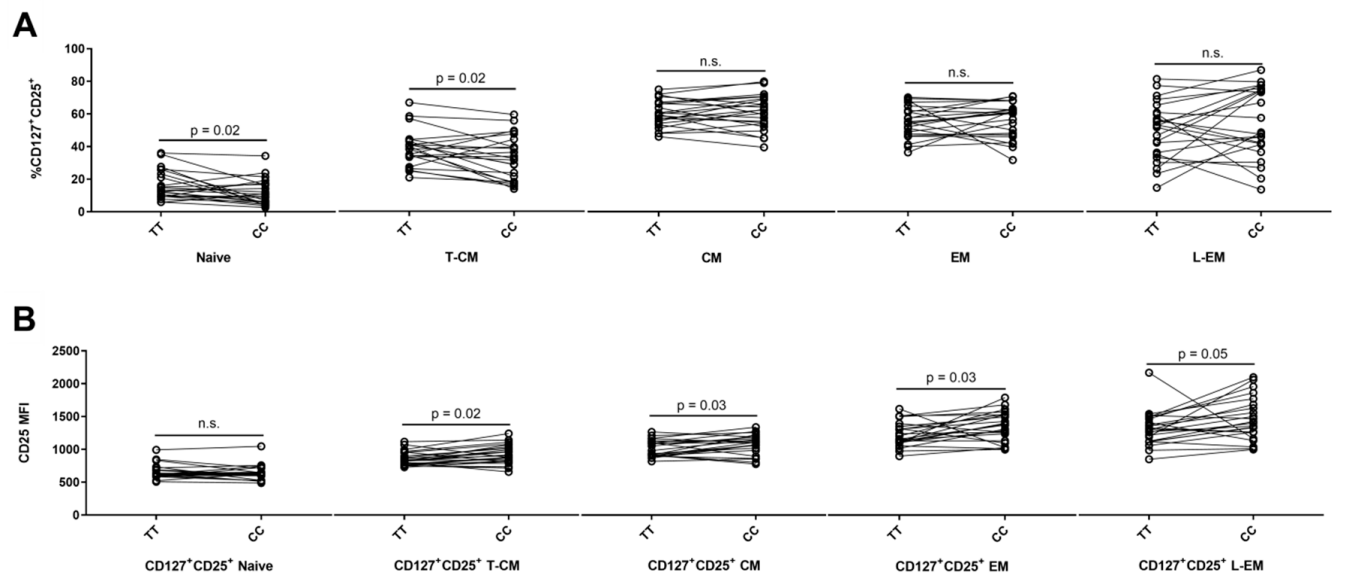

Figure 2. IL2RA genotype associations on differentiation of $\mathrm{CD} 4^{+} \mathrm{T}$ cells. Homozygous carriers of both MS-associated IL2RA SNPs, rs2104286 and rs11256593, are defined by TT for the risk genotype $(\mathrm{N}=23)$ and $\mathrm{CC}$ for the protective genotype $(\mathrm{N}=23)$. Gating strategy is outlined in Figure 1A-E. (A) Differences between TT carriers and CC carriers on frequency of $\mathrm{CD} 127^{+} \mathrm{CD} 25^{+}$naïve (Paired t test, mean of difference $=-4.6 ; 95 \% \mathrm{CI}=-8.5$ to -0.7 ), T-CM (Paired t test, mean of difference $=-5.6 ; 95 \%$ $\mathrm{CI}=-10.4$ to -0.9 ), $\mathrm{CM}$ (Paired $\mathrm{t}$ test, mean of difference $=0.6 ; 95 \% \mathrm{CI}=-2.7$ to 3.9 ), $\mathrm{EM}$ (Paired $\mathrm{t}$ test, mean of difference $=1.2 ; 95 \% \mathrm{CI}=-4.0$ to 6.4 ) and L-EM cells (Paired $t$ test, mean of difference $=$ $5.1 ; 95 \% \mathrm{CI}=-3.6$ to 13.8$)$. (B) Differences between TT carriers $(\mathrm{N}=23)$ and CC carriers $(\mathrm{N}=23)$ on surface expression (MFI) of CD25 on CD127 ${ }^{+} \mathrm{CD} 25^{+}$naïve (Paired t test, mean of difference $=-16.9$; $95 \% \mathrm{CI}=-56.5$ to 22.8 ), $\mathrm{T}-\mathrm{CM}$ (Paired $\mathrm{t}$ test, mean of difference $=63.9 ; 95 \% \mathrm{CI}=13$ to 114.8 ), $\mathrm{CM}$ (Paired $\mathrm{t}$ test, mean of difference $=61.5 ; 95 \% \mathrm{CI}=5.6$ to 117.4), EM (Paired $\mathrm{t}$ test, mean of difference $=120 ; 95 \%$ $\mathrm{CI}=13.4$ to 226.7 ) and L-EM cells (Paired $\mathrm{t}$ test, mean of difference $=153.9 ; 95 \% \mathrm{CI}=0.9$ to 306.8 ).

\subsection{The MS-Associated IL2RA Risk Genotype Has Few Associations with CD25 Expression on CD8 ${ }^{+} \mathrm{T} C e l l s$}

In $\mathrm{CD}^{+} \mathrm{T}$ cells, expression of CD127 and CD25 defined the same two populations as in CD4 ${ }^{+} \mathrm{T}$ cells (Figure 1J). The $\mathrm{CD} 127^{+} \mathrm{CD} 25^{+}$population represented $8.4 \%$ (IQR: $6.0-12.1 \%$ ). The $\mathrm{CD} 127^{+} \mathrm{CD} 25^{+}$ gate was applied to the six $\mathrm{CD}^{+} \mathrm{T}$ cell differentiation subsets (Figure $1 \mathrm{H}$ ). We found that the T-CM population had the highest frequency of $\mathrm{CD} 127^{+} \mathrm{CD} 25^{+}$cells among $\mathrm{CD} 8^{+} \mathrm{T}$ cells (Figure $1 \mathrm{~L}$ ) and that carriers of the risk genotype (TT) had a suggestively lower frequency of CD $127^{+} \mathrm{CD} 25^{+} \mathrm{T}-\mathrm{CM}$ cells (Table 2: $p=0.03$ ). We observed no associations of the MS-associated IL2RA genotype with frequency or surface expression (MFI) of CD25 on the other $\mathrm{CD} 127^{+} \mathrm{CD} 25^{+} \mathrm{CD} 8^{+} \mathrm{T}$ cell subsets (Table 2). In CD8 ${ }^{+}$ $\mathrm{T}$ cells, the $\mathrm{CD} 127{ }^{\mathrm{lo}} \mathrm{CD} 25^{\mathrm{hi}}$ population only represented $0.49 \%$ (IQR: $0.24-1.2 \%$ ) and therefore excluded from statistical analysis.

Table 2. IL2RA genotype effects on the $\mathrm{CD} 127^{+} \mathrm{CD} 25^{+}$population in relation to $\mathrm{CD} 8^{+} \mathrm{T}$ cell differentiation. A risk genotype (TT) is defined as a homozygous carrier of the risk allele (T) for both MS-associated IL2RA SNPs rs2104286 and rs11256593. A protective genotype (CC) is defined as a homozygous carrier of the protective allele (C) for both MS-associated IL2RA SNPs rs2104286 and rs11256593.

\begin{tabular}{|c|c|c|c|c|c|c|c|}
\hline \multirow[t]{2}{*}{ Subset * } & \multirow[t]{2}{*}{$\mathbf{N}_{\text {Pair }}$} & \multicolumn{2}{|c|}{$\begin{array}{l}\text { Median Frequency of } \\
\mathrm{CD}_{2} 27^{+} \mathrm{CD} 25^{+} \text {Cells }\end{array}$} & \multirow{2}{*}{$\begin{array}{l}\text { Wilcoxon } \\
\text { Signed } \\
\text { Rank Test }\end{array}$} & \multicolumn{2}{|c|}{$\begin{array}{l}\text { Median MFI }{ }^{* *} \text { of CD25 } \\
\text { on CD127 }{ }^{+} \text {CD } 25^{+} \text {Cells }\end{array}$} & \multirow{2}{*}{$\begin{array}{c}\text { Wilcoxon } \\
\text { Signed } \\
\text { Rank Test }\end{array}$} \\
\hline & & CC & TT & & $\mathrm{CC}$ & TT & \\
\hline Naive & 23 & 3.4 & 2.7 & n.s. & 728 & 610 & n.s. \\
\hline T-CM & 23 & 34.3 & 25.2 & 0.03 & 972 & 866 & n.s. \\
\hline $\mathrm{CM}$ & 23 & 34.7 & 35.8 & n.s. & 1337 & 1240 & n.s. \\
\hline EM & 23 & 12.3 & 11.8 & n.s. & 1296 & 1269 & n.s. \\
\hline L-EM & 23 & 9.6 & 7.7 & n.s. & 892 & 827 & n.s. \\
\hline $\mathrm{T}_{\mathrm{EMRA}}$ & 23 & 0.9 & 0.7 & n.s. & 745 & 788 & n.s. \\
\hline
\end{tabular}

* Subset abbreviations: T-CM = Transitional central memory; CM = Central memory; EM = Effector memory; L-EM $=$ Late-EM; $\mathrm{T}_{\mathrm{EMRA}}=$ Terminally differentiated effector memory. ${ }^{* *} \mathrm{MFI}=$ median fluorescence intensity. $p$ value depicting a trend for association is indicated in italics. 
3.3. MS-Associated IL2RA Risk Genotype Associations on CD31 ${ }^{+}$Recent Thymic Emigrant (RTE) and Non-RTE CD45RA ${ }^{+}$CD4 ${ }^{+}$T Cells

CD31 expression distinguishes $\mathrm{CD} 31^{+} \mathrm{CD} 45 \mathrm{RA}^{+} \mathrm{CD} 4^{+} \mathrm{T}$ cells that are recent thymic emigrants (RTE) from $\mathrm{CD} 31^{-} \mathrm{CD} 45 \mathrm{RA}^{+} \mathrm{CD} 4^{+} \mathrm{T}$ cells that have undergone post-thymic peripheral expansion [52]. In our study, the majority of $\mathrm{CD} 45 \mathrm{RA}^{+} \mathrm{CD}^{+} \mathrm{T}$ cells represented naïve and T-CM cells (Figure 1B). To exclude contamination from $\mathrm{T}_{\text {Reg }}$ cells, we gated RTE and CD31-CD45RA ${ }^{+}$cells on CD127 ${ }^{+}$cells (Figure 3C). RTE cells comprised 27\% (IQR: 20-37\%) of CD4 ${ }^{+} \mathrm{T}$ cells (Figure 3F) and carriers of the risk genotype (TT) had a suggestively higher frequency of CD25 $5^{+}$RTE cells $(p=0.006)$ compared to carriers of the protective genotype (CC) (Figure 3G). However, we observed no difference in the expression (MFI) of CD25 on CD25 $5^{+}$RTE cells in relation to the IL2RA genotype (Figure 3H). In CD31- CD45RA ${ }^{+}$ cells, representing $25 \%$ (IQR: $20-32 \%$ ) of $\mathrm{CD}^{+} \mathrm{T}$ cells (Figure 3F), we observed that carriers of the risk genotype (TT) had a suggestively decreased surface expression of CD25 on CD25+ CD31-CD45RA ${ }^{+}$ cells $(p=0.01)$ compared to carriers of the protective genotype (CC) (Figure 3J), but we found no IL2RA genotype associations with the frequency of $\mathrm{CD} 25^{+} \mathrm{CD}^{-} 1^{-} \mathrm{CD} 45 \mathrm{RA}{ }^{+}$cells (Figure $3 \mathrm{I}$ ).

\subsection{Lower Frequency of CD25 $5^{+} T_{F H} 1$ Cells in Carriers of the IL2RA Risk Genotype}

Blood $\mathrm{T}$ follicular helper $\left(\mathrm{T}_{\mathrm{FH}}\right)$ cells can be identified by surface expression of CXCR5 and PD-1 $[20,53]$. The PD- $1^{+} \mathrm{CXCR}^{+}\left(\mathrm{T}_{\mathrm{FH}}\right)$ cells were gated on $\mathrm{CD} 127^{+}$cells to exclude contamination from $\mathrm{T}_{\text {Reg }}$ cells (Figure $4 \mathrm{~B}$ ) and comprised 3.1\% (IQR: 2.0-3.8\%) of CD4 ${ }^{+} \mathrm{T}$ cells. Carriers of the risk genotype (TT) had a suggestively lower frequency of $\mathrm{CD} 25^{+} \mathrm{T}_{\mathrm{FH}}$ cells $(p=0.02)$ compared to carriers of the protective genotype (CC) (Figure 4G). Differential surface expression of chemokine receptors CXCR3 and CCR6 separates $\mathrm{T}_{\mathrm{FH}} 1\left(\mathrm{CCR}^{-} \mathrm{CXCR}^{+}\right), \mathrm{T}_{\mathrm{FH}} 2\left(\mathrm{CCR}^{-} \mathrm{CXCR}^{-}\right)$, and $\mathrm{T}_{\mathrm{FH}} 17\left(\mathrm{CCR} 6^{+} \mathrm{CXCR} 3^{-}\right)$cells [54] (Figure 4E). $\mathrm{T}_{\mathrm{FH}} 1$ cells made up the largest group of $\mathrm{T}_{\mathrm{FH}}$ cells (Figure $4 \mathrm{I}$ ) and we found that carriers of the risk genotype had a significantly lower frequency of $\mathrm{CD} 25^{+} \mathrm{T}_{\mathrm{FH}} 1$ cells $(p=0.001)$ while we observed no IL2RA genotype associations on the $\mathrm{T}_{\mathrm{FH}} 2$ and $\mathrm{T}_{\mathrm{FH}} 17$ cells (Figure $4 \mathrm{~J}$ ). We observed no IL2RA genotype associations with surface expression levels of $C D 25$ on the $C D 25^{+} T_{F H}$ subsets (Figure $4 \mathrm{~K}$ ). 
A
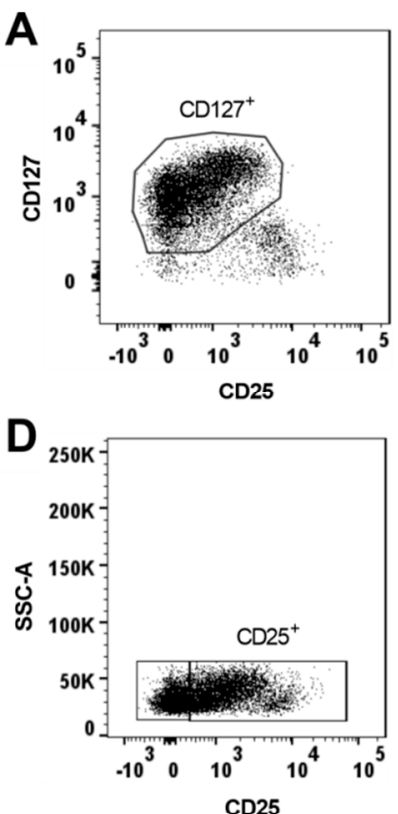

B

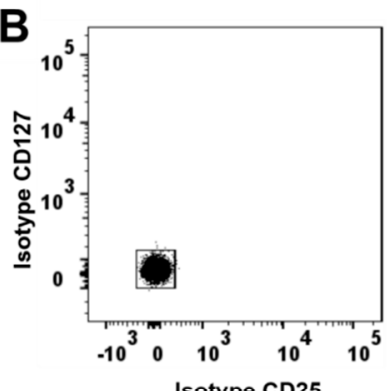

E

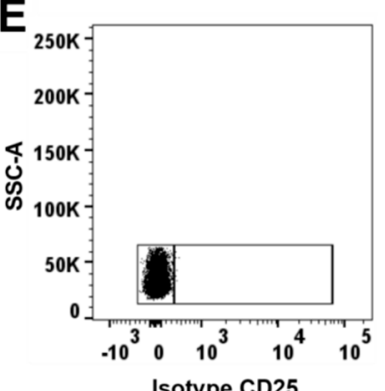

C

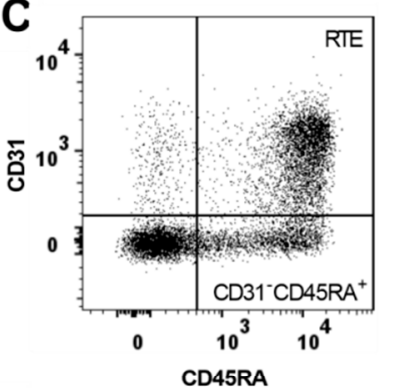

F

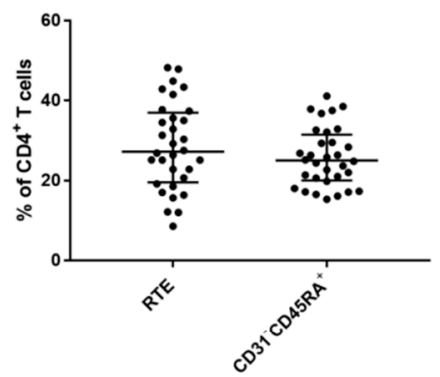

G

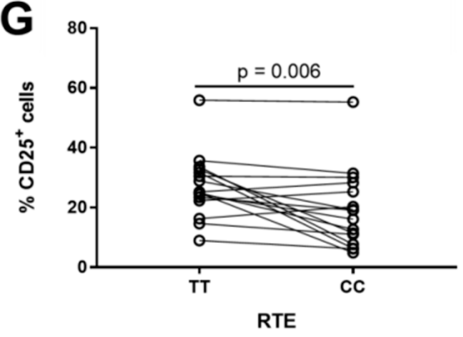

I

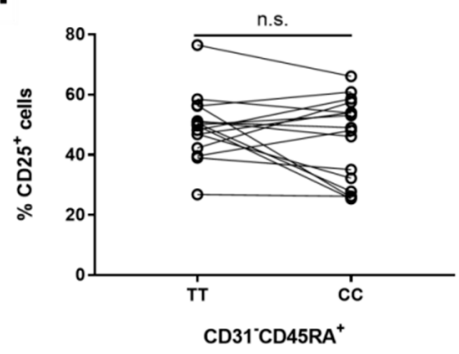

H

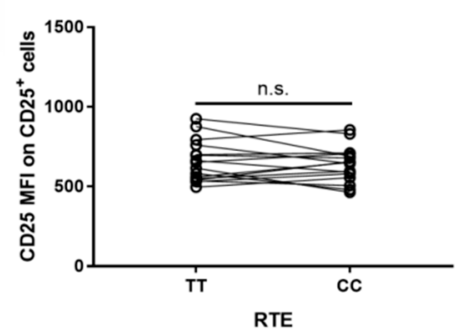

J

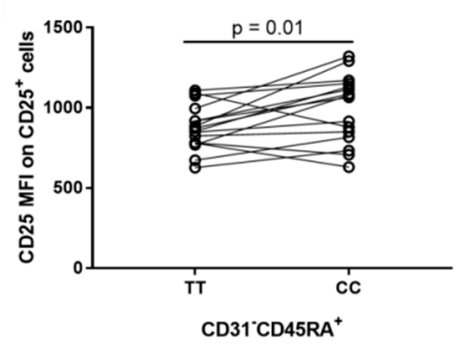

Figure 3. IL2RA genotype associations on recent thymic emigrants and $\mathrm{CD} 31^{-} \mathrm{CD} 45 \mathrm{RA}{ }^{+} \mathrm{CD}^{+} \mathrm{T}$ cells. (A) Gating of $\mathrm{CD} 127^{+}$cells on $\mathrm{CD} 4^{+} \mathrm{T}$ cells by use of matched isotype control. (B) Matched isotype control for CD25 and CD127 on CD4 ${ }^{+} \mathrm{T}$ cells. (C) Gating of recent thymic emigrants $\left(\mathrm{RTE} ; \mathrm{CD}^{+} 1^{+} \mathrm{CD} 45 \mathrm{RA}^{+}\right)$and $\mathrm{CD} 31^{-} \mathrm{CD} 45 \mathrm{RA}^{+}$cells. RTE and $\mathrm{CD}^{-} 1^{-} \mathrm{CD} 45 \mathrm{RA}^{+}$cells are gated from $\mathrm{CD} 127^{+} \mathrm{CD}^{+} \mathrm{T}$ cells to exclude contamination from $\mathrm{T}_{\text {Reg }}$ cells. (D) Gating of CD25 ${ }^{+}$cells on CD4 ${ }^{+} \mathrm{T}$ cells by use of matched isotype control. (E) Matched isotype control for CD25. (F) Frequency of recent thymic emigrant (RTE; CD31 ${ }^{+} \mathrm{CD} 45 \mathrm{RA}^{+}$) cells and $\mathrm{CD} 31^{-} \mathrm{CD} 45 \mathrm{RA}^{+}$cells in relation to $\mathrm{CD} 4^{+} \mathrm{T}$ cells. (G,I) Homozygous carriers of both MS-associated IL2RA SNPs rs2104286 and rs11256593 are defined by TT for the risk genotype and CC for the protective genotype. Differences between TT carriers $(\mathrm{N}=16)$ and $\mathrm{CC}$ carriers $(\mathrm{N}=16)$ on frequency of $\mathrm{CD}^{2} 5^{+}$cells in RTE (Paired t test, mean of difference $=-8.0$; 95\% CI $=-13.5$ to -2.6 ) and $\mathrm{CD}^{-} 1^{-} \mathrm{CD}^{2} 5 \mathrm{RA}^{+}$(Paired $\mathrm{t}$ test, mean of difference $=-4.3 ; 95 \% \mathrm{CI}=-11.4$ to 2.7) $\mathrm{T}$ cells. $(\mathrm{H}, \mathrm{J})$ Differences between TT carriers $(\mathrm{N}=16)$ and CC carriers $(\mathrm{N}=16)$ on surface expression (MFI) of CD25 in CD25 ${ }^{+} \mathrm{RTE}$ (Paired t test, mean of difference $=-17.8 ; 95 \% \mathrm{CI}=-67.1$ to 31.6) and $\mathrm{CD}^{+} 5^{+} \mathrm{CD} 31^{-} \mathrm{CD} 45 \mathrm{RA}^{+}$(Paired t test, mean of difference $=120.3 ; 95 \% \mathrm{CI}=29.3$ to 211.3 ) cells. 

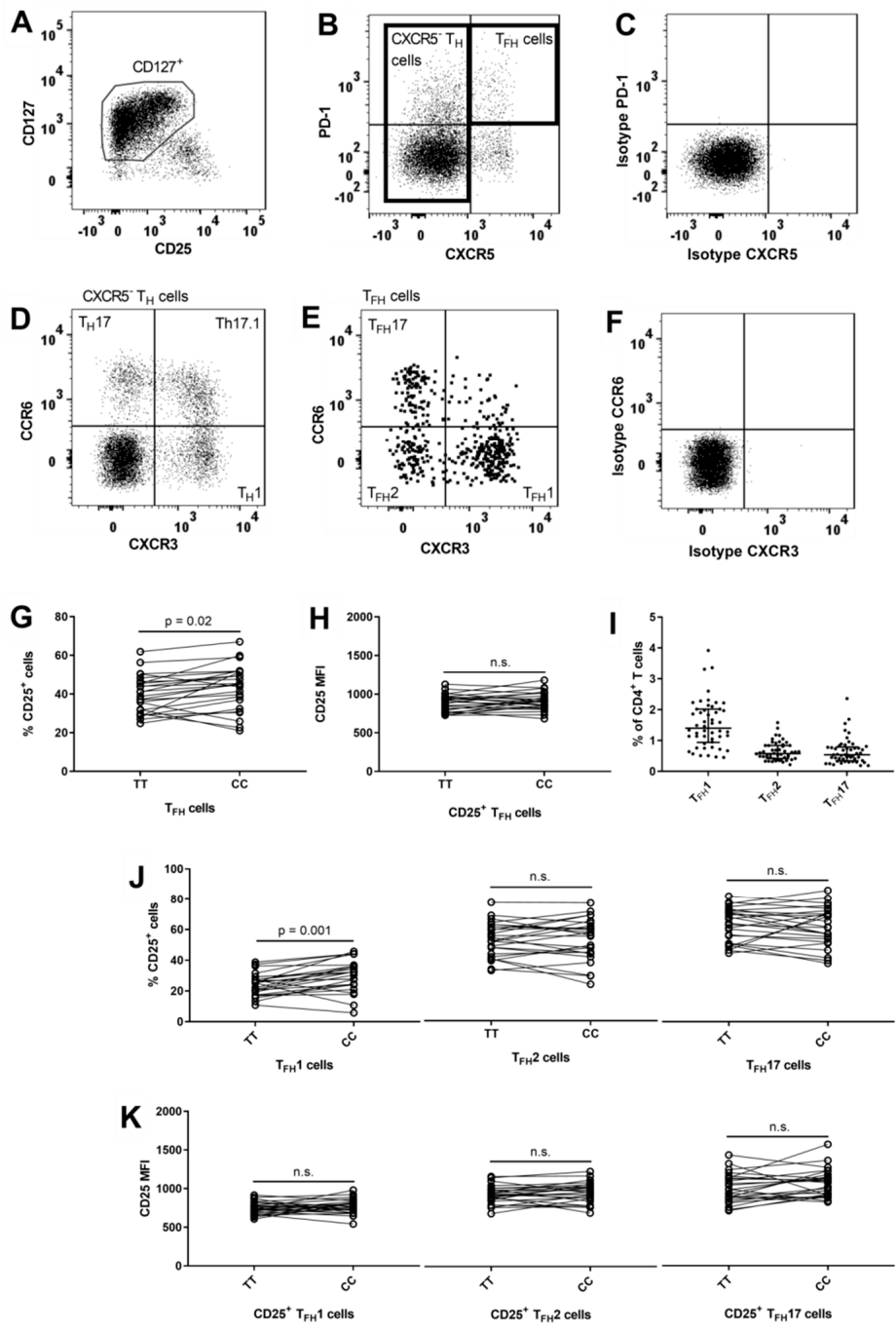

Figure 4. IL2RA genotype associations on $\mathrm{CD}^{+} \mathrm{T}$ follicular helper subsets. (A) Gating of $\mathrm{CD} 127^{+}$cells on $\mathrm{CD}^{+} \mathrm{T}$ cells by use of matched isotype control. (B) Gating of CXCR5 $5^{-}$cells, defined as non-follicular T helper $\left(\mathrm{CXCR} 5^{-} \mathrm{T}_{\mathrm{H}}\right)$ cells and $\mathrm{T}$ follicular helper $\left(\mathrm{T}_{\mathrm{FH}}\right)$ cells, defined by being PD- $1^{+} \mathrm{CXCR} 5^{+}$. Gating

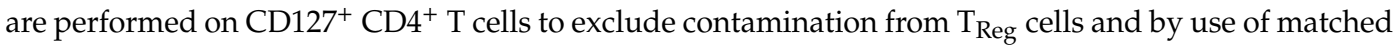
isotype control. (C) Matched isotype control for CXCR5 and PD-1 on CD4 ${ }^{+}$T cells. (D) On CXCR5 ${ }^{-}$ $\mathrm{T}_{\mathrm{H}}$ cells, differential expression of $\mathrm{CXCR} 3$ and CCR6 defines three subsets: $\mathrm{T}_{\mathrm{H}} 1\left(\mathrm{CXCR} 3^{+} \mathrm{CCR} 6^{-}\right)$, Th17.1 $\left(\mathrm{CXCR}^{+}{ }^{+} \mathrm{CCR} 6^{+}\right)$and $\mathrm{T}_{\mathrm{H}} 17\left(\mathrm{CXCR}^{-}{ }^{-} \mathrm{CCR} 6^{+}\right)$. Gating are performed by use matched isotype control. (E) On $\mathrm{T}_{\mathrm{FH}}$ cells, differential expression of CXCR3 and CCR6 defines tree subsets: $\mathrm{T}_{\mathrm{FH}} 1$ $\left(\mathrm{CXCR}^{+}{ }^{+} \mathrm{CCR} 6^{-}\right), \mathrm{T}_{\mathrm{FH}} 2\left(\mathrm{CXCR}^{-} \mathrm{CCR}^{-}\right)$and $\mathrm{T}_{\mathrm{FH}} 17$ (CXCR3 $\left.{ }^{-} \mathrm{CCR}^{+} \mathrm{T}_{\mathrm{FH}}\right)$. Gating are performed by use matched isotype control. (F) Matched isotype control for CCR6 and CXCR3 on CD4 ${ }^{+}$T cells. $(\mathbf{G}, \mathbf{H})$ Homozygous carriers of both MS-associated IL2RA SNPs rs2104286 and rs11256593 are defined by TT for the risk genotype $(\mathrm{N}=25)$ and $\mathrm{CC}$ for the protective genotype $(\mathrm{N}=25)$. Difference between TT and $\mathrm{CC}$ carriers on the frequency of $\mathrm{CD}_{2} 5^{+}$cells in $\mathrm{T}_{\mathrm{FH}}$ cells (Paired t test, mean of difference $=3.7 ; 95 \% \mathrm{CI}=$ 0.7 to 6.7) and the surface expression (MFI) of CD25 on CD25 ${ }^{+} \mathrm{T}_{\mathrm{FH}}$ cells (Paired t test, mean of difference $=20.7 ; 95 \% \mathrm{CI}=-20$ to 61.4$)$. (I) Frequency of $\mathrm{T}_{\mathrm{FH}} 1\left(\mathrm{CXCR}^{+} \mathrm{CCR}^{-} \mathrm{T}_{\mathrm{FH}}\right), \mathrm{T}_{\mathrm{FH}} 2\left(\mathrm{CXCR}^{-} \mathrm{CCR}^{-} \mathrm{T}_{\mathrm{FH}}\right)$ and $\mathrm{T}_{\mathrm{FH}} 17\left(\mathrm{CXCR}^{-}{ }^{-} \mathrm{CCR} 6^{+} \mathrm{T}_{\mathrm{FH}}\right)$ cells in relation to $\mathrm{CD}^{+} \mathrm{T}$ cells. $(\mathbf{J}, \mathbf{K})$ Difference between carriers of the IL2RA risk genotype TT $(\mathrm{N}=25)$ and the protective genotype $C C(\mathrm{~N}=25)$ on the frequency of $\mathrm{CD}_{2} 5^{+}$cells in $\mathrm{T}_{\mathrm{FH}} 1$ (Paired t test, mean of difference $=5.6 ; 95 \% \mathrm{CI}=2.4$ to 8.7 ), $\mathrm{T}_{\mathrm{FH}} 2$ (Paired $\mathrm{t}$ test, mean of difference $=0.1 ; 95 \% \mathrm{CI}=-3.2$ to 3.4) and $\mathrm{T}_{\mathrm{FH}} 17$ (Paired t test, mean of difference $=-1 ; 95 \% \mathrm{CI}$ $=-4.8$ to 2.9 ) cells and the surface expression (MFI) of CD25 on CD25 ${ }^{+} \mathrm{T}_{\mathrm{FH}} 1$ (Paired t test, mean of difference $=23.1 ; 95 \% \mathrm{CI}=-20.6$ to 66.8$), \mathrm{CD} 25^{+} \mathrm{T}_{\mathrm{FH}} 2$ (Paired $\mathrm{t}$ test, mean of difference $=20.6$; $95 \% \mathrm{CI}$ $=-22.5$ to 63.8 ), and $\mathrm{CD} 25^{+} \mathrm{T}_{\mathrm{FH}} 17$ (Paired t test, mean of difference $=63 ; 95 \% \mathrm{CI}=-10.2$ to 136.2 ) cells. 
3.5. Reduced Surface Expression of CD25 on CXCR5 $5^{-} T_{H} 1$ and $T_{H} 17$ Cells in Carriers of the IL2RA Risk Genotype

Non-follicular helper $\mathrm{T}\left(\mathrm{T}_{\mathrm{H}}\right)$ cells, defined as CXCR5- and $\mathrm{CD} 127^{+}$(Figure $4 \mathrm{~B}$ ), comprised $80 \%$ (IQR: 77-82\%) of $\mathrm{CD}^{+} \mathrm{T}$ cells. We observed that carriers of the risk genotype had a significantly lower surface expression of CD25 ( $p=0.002)$ on $\mathrm{CD} 4{ }^{+} \mathrm{CD} 25^{+} \mathrm{CXCR}^{-} \mathrm{T}_{\mathrm{H}}$ cells (Figure $5 \mathrm{~B}$ ). Chemokine receptors CXCR3 and CCR6 can distinguish lineage commitment of $C X C R 5^{-} \mathrm{T}_{\mathrm{H}}$ cells and defines three subsets: $\mathrm{T}_{\mathrm{H}} 1\left(\mathrm{CCR}^{-} \mathrm{CXCR3}^{+}\right)$[55]; Th17.1 $\left(\mathrm{CCR}^{+}{ }^{+} \mathrm{CXCR}^{+}\right)$[56,57] and $\mathrm{T}_{\mathrm{H}} 17\left(\mathrm{CCR}^{+}{ }^{+} \mathrm{CXCR} 3^{-}\right)[56,58]$ (Figure 4D). Distribution of the three CXCR5 ${ }^{-} \mathrm{T}_{\mathrm{H}}$ subsets can be seen in Figure $5 \mathrm{C}$. Carriers of the risk genotype (TT) had a suggestively lower frequency of CD25 $5^{+}$Th17.1 cells $(p=0.04)$ and CD25 $\mathrm{T}_{\mathrm{H}} 1$ cells $(p=0.03)$ compared to the protective genotype (Figure 5D). In addition, carriers of the risk genotype (TT) had a significant decrease in surface expression of CD25 on CD25 $5^{+} \mathrm{T}_{\mathrm{H}} 1(p=0.001)$ and $\mathrm{CD} 25^{+} \mathrm{T}_{\mathrm{H}} 17$ cells $(p=0.005)$ and a suggestively lower surface expression of CD25 on CD25 $5^{+}$Th17.1 ( $p=0.007)$ cells compared to carriers of the protective genotype (CC) (Figure 5E).
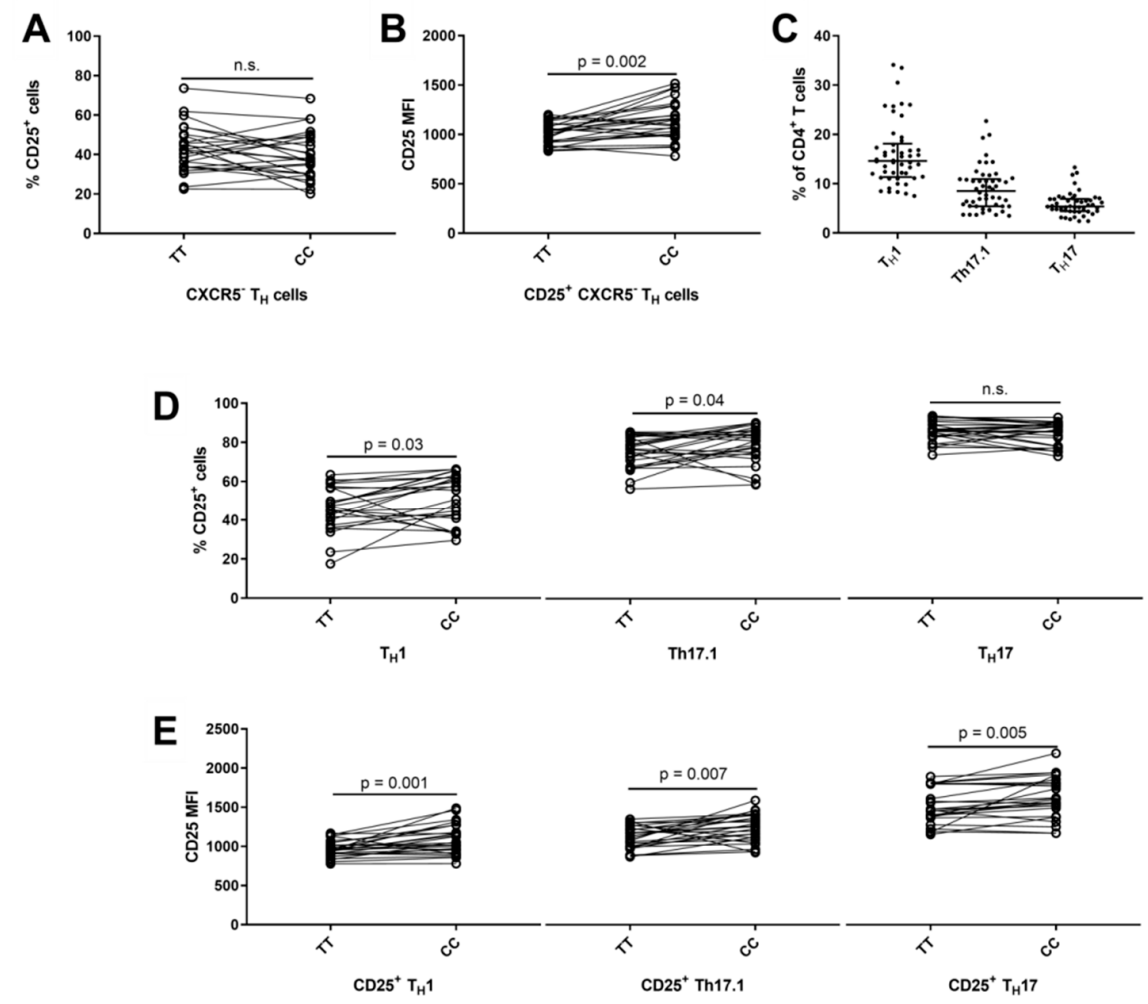

Figure 5. IL2RA genotype associations on $\mathrm{CD}^{+}$non-follicular T helper subsets. Non-follicular T helper $\left(\mathrm{T}_{\mathrm{H}}\right)$ subsets are defined by being $\mathrm{CXCR} 5^{-}$and gated from $\mathrm{CD} 127^{+}$cells to exclude contamination from $\mathrm{T}_{\text {Reg }}$ cells (Figure 4B). (A,B) Homozygous carriers of both MS-associated IL2RA SNPs rs2104286 and rs11256593 are defined by TT for the risk genotype and CC for the protective genotype. Difference between TT carriers $(\mathrm{N}=25)$ and the protective genotype CC $(\mathrm{N}=25)$ on the frequency of $\mathrm{CD} 25^{+}$cells in CXCR5 ${ }^{-} \mathrm{T}_{\mathrm{H}}$ cells (Paired t test, mean of difference $=-3.4 ; 95 \% \mathrm{CI}=-7.9$ to 1.2 ) and the surface expression (MFI) of CD25 on CD25 ${ }^{+}$CXCR5 $^{-} \mathrm{T}_{\mathrm{H}}$ cells (Paired $\mathrm{t}$ test, mean of difference $=121.7 ; 95 \%$ $\mathrm{CI}=50.3$ to 193.1). (C) Frequency of $\mathrm{T}_{\mathrm{H}} 1\left(\mathrm{CXCR}^{+} \mathrm{CCR}^{-} \mathrm{CXCR}^{-} \mathrm{T}_{\mathrm{H}}\right)$, Th17.1 $\left(\right.$ CXCR3 $^{+} \mathrm{CCR}^{+}$ $\mathrm{CXCR}^{-} \mathrm{T}_{\mathrm{H}}$ ) and $\mathrm{T}_{\mathrm{H}} 17$ (CXCR3 ${ }^{-} \mathrm{CCR}^{+} \mathrm{CXCR}^{-} \mathrm{T}_{\mathrm{H}}$ ) cells in relation to $\mathrm{CD}^{+}{ }^{+} \mathrm{T}$ cells (gating outlined in Figure 4D). $(\mathbf{D}, \mathbf{E})$ Difference between TT carriers $(\mathrm{N}=25)$ and $\mathrm{CC}$ carriers $(\mathrm{N}=25)$ on the frequency of $\mathrm{CD}_{2} 5^{+}$cells in the $\mathrm{T}_{\mathrm{H}} 1$ (Paired $\mathrm{t}$ test, mean of difference $=5.5 ; 95 \% \mathrm{CI}=0.6$ to 10.5), Th17.1 (Paired $\mathrm{t}$ test, mean of difference $=4.2 ; 95 \% \mathrm{CI}=0.1$ to 8.3 ) and $\mathrm{T}_{\mathrm{H}} 17$ (Paired $\mathrm{t}$ test, mean of difference $=-1.1$; $95 \% \mathrm{CI}=-3.4$ to 1.2 ) subset and the surface expression (MFI) of CD25 on CD25 $5^{+} \mathrm{T}_{\mathrm{H}} 1$ (Paired t test, mean of difference $=120.2 ; 95 \% \mathrm{CI}=52.7$ to 187.6), Th17.1 (Paired $\mathrm{t}$ test, mean of difference $=116.8$; $95 \% \mathrm{CI}=35.6$ to 198.1 ) and $\mathrm{T}_{\mathrm{H}} 17$ (Paired t test, mean of difference $=113.5 ; 95 \% \mathrm{CI}=38.7$ to 188.4 ) cells. 
3.6. MS-Associated IL2RA Genotype Associations with Surface Expression of CD25 on $T_{\text {Reg }}$ Cell Populations

The $\mathrm{T}_{\text {Reg }}\left(\mathrm{CD} 127^{\mathrm{lo}} \mathrm{CD} 25^{\mathrm{hi}}\right)$ population comprised 7.4\% (IQR: 6.6-8.6\%) of CD4 ${ }^{+} \mathrm{T}$ cells. Expression of CD39 can identify a committed $\mathrm{T}_{\text {Reg }}$ cell [59] (Figure 6B). CD39 ${ }^{+} \mathrm{CD} 45 \mathrm{RA}{ }^{-} \mathrm{T}_{\text {Reg }}$ cells comprised 2.4\% (IQR: $0.9-3.0 \%$ ) of $\mathrm{CD}^{+} \mathrm{T}$ cells (Figure $6 \mathrm{D}$ ) and carriers of the risk genotype (TT) had a suggestively lower surface expression of CD25 on CD39+CD45RA ${ }^{-} \mathrm{T}_{\text {Reg }}$ cells $(p=0.02)$ (Figure $6 \mathrm{E}$ ). As in non-regulatory $\mathrm{CD}^{+}{ }^{+} \mathrm{T}$ cells, CD31 can identify CD45RA ${ }^{+} \mathrm{T}_{\text {Reg }}$ cells that are RTE [36] (Figure 6C), a population that in our study comprised $1.5 \%$ (IQR: $0.7-2.0 \%$ ) of $C D 4^{+} \mathrm{T}$ cells. However, we found no difference between IL2RA genotypes in CD25 expression (data not shown).

Finally, we applied the $\mathrm{T}_{\mathrm{Reg}}\left(\mathrm{CD} 127^{\mathrm{lo}} \mathrm{CD} 25^{\mathrm{hi}}\right)$ gate to each of the CD45RA/CCR7 subsets defined in Section 3.1 on $\mathrm{CD}^{+} \mathrm{T}$ cells (Figure 1B). We found that the highest frequency of $\mathrm{T}_{\text {Reg }}$ cells was in the EM (CD45RA ${ }^{-} \mathrm{CCR7}^{-}$) population in relation to $\mathrm{CD}^{+} \mathrm{T}$ cells (Figure 6F). Risk genotype (TT) carriers had a suggestively lower surface expression of CD25 on $\mathrm{T}_{\text {Reg }}$ cells with an EM phenotype $(p=0.01)$ (Figure 6G). Approximately no $\mathrm{T}_{\mathrm{EMRA}}$ cells had a $\mathrm{T}_{\text {Reg }}$ phenotype and therefore this subset was excluded from statistical analysis. 
A

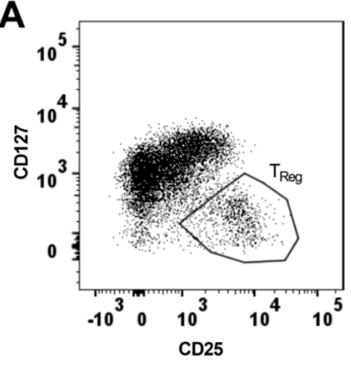

D

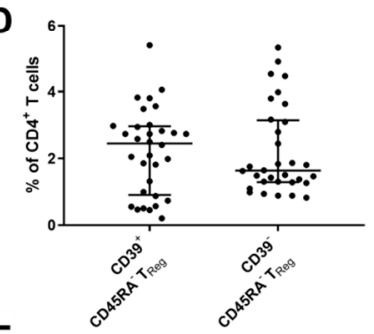

$\mathbf{F}$

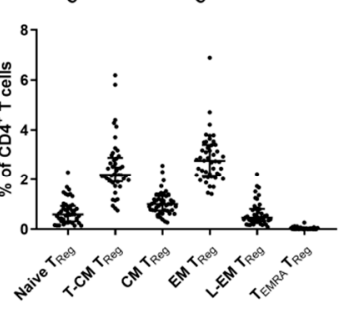

B

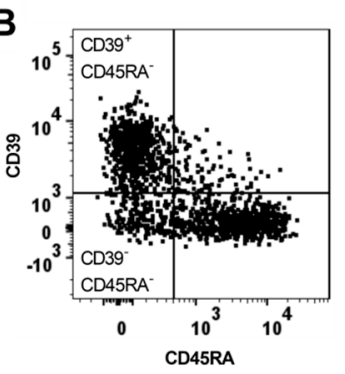

C

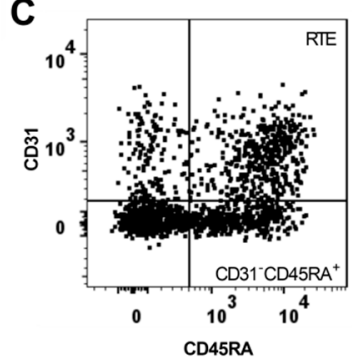

E

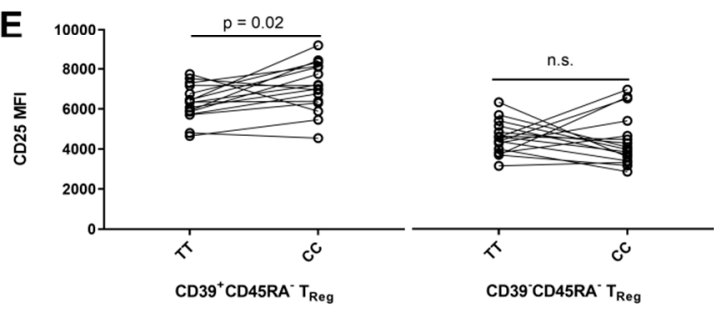

G
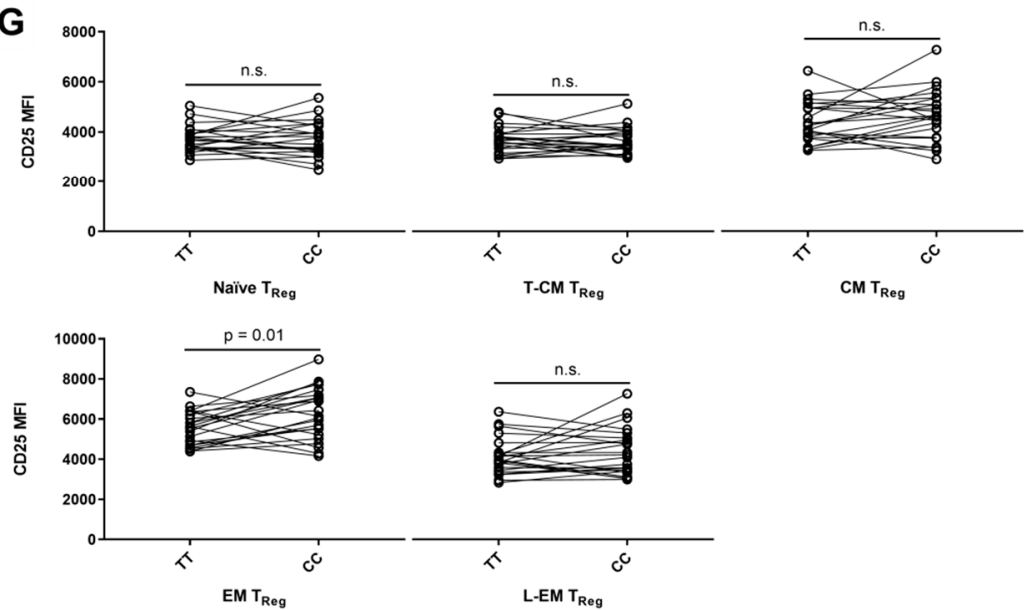

Figure 6. IL2RA genotype associations on $C D 4^{+} \mathrm{T}_{\text {Reg }}$ subsets. (A) Gating of $\mathrm{T}_{\text {Reg }}$ cells, defined by being $\mathrm{CD} 127^{\mathrm{lo}} \mathrm{CD} 25^{\mathrm{hi}}$. (B) $\mathrm{T}_{\text {Reg }}$ cells are gated by expression of CD39 and CD45RA in two subsets: $\mathrm{CD}_{39^{+}} \mathrm{CD} 45 \mathrm{RA}^{-}$(committed $\mathrm{T}_{\text {Reg }}$ cells) and $\mathrm{CD} 39^{-} \mathrm{CD} 45 \mathrm{RA}^{-}$. (C) $\mathrm{T}_{\text {Reg }}$ cells are gated by expression of CD31 and CD45RA in two subsets: Recent thymic emigrants (RTE; CD $31^{+} \mathrm{CD}_{4} 4 \mathrm{RA}^{+}$) and $\mathrm{CD} 1^{-} \mathrm{CD} 45 \mathrm{RA}^{+}$. (D) Frequency of CD39 ${ }^{+} \mathrm{CD} 45 \mathrm{RA}^{-}$and $\mathrm{CD} 39^{-} \mathrm{CD} 45 \mathrm{RA}^{-} \mathrm{T}_{\mathrm{Reg}}$ in relation to $\mathrm{CD} 4^{+}$ T cells. (E) Homozygous carriers of both MS-associated IL2RA SNPs rs2104286 and rs11256593 are defined by TT for the risk genotype and CC for the protective genotype. Differences between carriers of the risk genotype TT $(\mathrm{N}=16)$ and carriers of the protective genotype CC $(\mathrm{N}=16)$ on surface expression of $\mathrm{CD} 25$ (MFI) on $\mathrm{CD}^{-} 9^{+} \mathrm{CD} 45 \mathrm{RA}^{-}$(Paired $\mathrm{t}$ test, mean of difference $=800.9 ; 95 \% \mathrm{CI}=175.2$ to 1427 ) and $\mathrm{CD}^{-} 9^{-} \mathrm{CD} 4 \mathrm{RA}^{-} \mathrm{T}_{\mathrm{Reg}}$ (Paired $\mathrm{t}$ test, mean of difference $=-110 ; 95 \% \mathrm{CI}=-956.9$ to 736.9 ) cells. (F) Frequency of naïve $\left(C D 45 R A^{\text {hi }} C C R 7^{+}\right)$, transitional central memory $(\mathrm{T}-\mathrm{CM})\left(\mathrm{CD} 45 \mathrm{RA} \mathrm{A}^{\text {lo-int }} \mathrm{CCR} 7^{+}\right)$, central memory $(\mathrm{CM})\left(\mathrm{CD}^{2} 5 \mathrm{RA}^{-} \mathrm{CCR} 7^{+}\right)$, effector memory (EM) $\left(\mathrm{CD} 45 \mathrm{RA}^{-} \mathrm{CCR} 7^{-}\right)$, late effector memory (L-EM) (CD45RA $\left.A^{\text {lo-int }} \mathrm{CCR}^{+}\right)$and $\mathrm{T}_{\mathrm{EMRA}}\left(\mathrm{CD} 45 \mathrm{RA}^{\text {hi }}{ }^{\mathrm{CCR}}{ }^{-}\right)$cells with a $\mathrm{T}_{\text {Reg }}$ phenotype in relation to $\mathrm{CD}^{+} \mathrm{T}$ cells. Gating for $\mathrm{CD} 4^{+} \mathrm{T}$ cell differentiation are outlined in Figure 1B. (G) Differences between TT carriers $(\mathrm{N}=23)$ and CC carriers $(\mathrm{N}=23)$ on surface expression (MFI) of CD25 on $\mathrm{T}_{\mathrm{Reg}}$ naïve (Paired $t$ test, mean of difference $=-25.9 ; 95 \% \mathrm{CI}=-303.2$ to 251.4), T-CM (Paired $t$ test, mean of difference $=-33 ; 95 \% \mathrm{CI}=-262.1$ to 196.1 ), $\mathrm{CM}$ (Paired $\mathrm{t}$ test, mean of difference $=278.1 ; 95 \%$ $\mathrm{CI}=-149.7$ to 706 ), $\mathrm{EM}$ (Paired $\mathrm{t}$ test, mean of difference $=720.6 ; 95 \% \mathrm{CI}=181.5$ to 1260 ) and $\mathrm{L}-\mathrm{EM}$ (Paired t test, mean of difference $=240.6 ; 95 \% \mathrm{CI}=-222.3$ to 703.5 ) cells. 


\section{Discussion}

Expression of CD25 is central in T cells responsiveness to IL-2 [7,8]. There is great heterogeneity in CD25 expression on T cell subtypes [7,8], however, the contributions from MS-associated IL2RA genetic variants are poorly understood. We have systematically explored how the MS-associated SNPs rs2104286 and rs11256593, in or near the IL2RA gene, that encode CD25, are associated with CD25 expression on $\mathrm{T}$ cells by multiparameter flow cytometry in genotype-selected healthy subjects.

We found that carriers of the MS-associated IL2RA risk genotype (TT) had reduced surface expression of $\mathrm{CD} 25$ on $\mathrm{CD} 25^{+} \mathrm{CD} 127^{+} \mathrm{CD} 4^{+} \mathrm{T}$ cells that had undergone post-thymic peripheral expansion $\left(\mathrm{CD}^{-} 1^{-} \mathrm{CD} 45 \mathrm{RA}^{+}\right)$or had a memory phenotype, such as CXCR5 ${ }^{-} \mathrm{T}_{\mathrm{H}}$ subsets or CD45RA ${ }^{-/ l o-i n t}$ cells including EM- $\mathrm{T}_{\text {Reg }}$ and $\mathrm{CD} 39^{+} \mathrm{CD}$ 45RA ${ }^{-} \mathrm{T}_{\text {Reg }}$ cells. Additionally, carriers of the risk genotype (TT) had a significantly lower frequency of $\mathrm{CD} 25^{+} \mathrm{T}_{\mathrm{FH}} 1$ cells and a suggestively lower frequency of CXCR5 $5^{-} \mathrm{CD} 25^{+} \mathrm{T}_{\mathrm{H}} 1$ and CD25 $5^{+}$Th17.1 cells. Finally, we confirmed that carriers of the risk genotype (TT) had an increased frequency of $\mathrm{CD} 25^{+} \mathrm{CD} 45 \mathrm{RA}^{+} \mathrm{CD} 4^{+} \mathrm{T}$ cells $[15,41]$ and we found that this was due to an increased frequency of $\mathrm{CD} 25^{+} \mathrm{CD} 45 \mathrm{RA}^{+} \mathrm{CD} 4^{+} \mathrm{T}$ cells that were recent thymic emigrants $\left(\mathrm{CD} 31^{+}\right)$.

Contrary to preceding studies $[15,40,41]$, we only compared healthy subjects homozygous for the risk (T) or protective (C) allele, for both MS-associated SNPs rs11256593 and rs2104286, to eliminate gene-dosage effects on phenotypes previously observed for the rs2104286 SNP [15]. Furthermore, compared to preceding studies $[15,40,41]$, we only included SNPs in or near the IL2RA gene associated with MS and did not include IL2RA SNPs associated with other autoimmune diseases which resulted in inclusion of the well-established SNP rs2104286 and the newly discovered SNP rs11256593 near the IL2RA gene from the MS-replication chip study [29]. In our cohort of a $1000 \mathrm{HCs}$ only $8.3 \%$ were homozygous for the protective allele (C) for SNP rs2104286 and therefore we were not able to reproduce findings in a secondary cohort and it was only possible to determine the combined association of the MS-associated SNPs rs2104286 and rs11256593 and not the independent associations of the rs2104286 and rs11256593 SNPs on expression of CD25 without compromising the size and pairing of the genotype groups. A study determining the independent associations of rs2104286 and rs11256593 on CD25 expression are warranted. However, the selection cohort of study participants should exceed $1000 \mathrm{HCs}$ as some IL2RA genotypes are rare.

Compared to previous studies, we applied a more in-depth phenotyping of $\mathrm{T}$ cell subsets including both $\mathrm{CD} 8^{+}$and $\mathrm{CD} 4^{+} \mathrm{T}$ cell subsets not previously studied $[15,40,41]$. In $\mathrm{CD} 8^{+} \mathrm{T}$ cells, we only observed a single suggestive difference although the number of individuals in each genotype group in $\mathrm{CD} 8^{+}$ $\mathrm{T}$ cells was the same as for $\mathrm{CD}^{+}{ }^{+} \mathrm{T}$ cells suggesting that MS-associated IL2RA SNPs rs2104286 and rs11256593 are associated with CD25 expression in $\mathrm{CD}^{+}{ }^{+}$, but not in $\mathrm{CD} 8^{+} \mathrm{T}$ cells. This is consistent with a previous study that observed that the rs2104286 SNP controls GM-CSF production in CD4 ${ }^{+}$ but not in $\mathrm{CD} 8^{+} \mathrm{T}$ cells [15]. In addition, we found MS-associated IL2RA gene variants rs2104286 and rs11256593 are associated differently with CD25 expression within $\mathrm{CD} 4^{+} \mathrm{T}$ cell subgroups. In $\mathrm{CD} 4^{+}$ $\mathrm{T}$ cells positive for either CD31 or CXCR5, MS-associated IL2RA variants were associated with the frequency of $\mathrm{CD} 25^{+}$cells but not the MFI of CD25. Contrary, in $\mathrm{CD} 4^{+} \mathrm{T}$ cells negative for either $\mathrm{CD} 31$ or CXCR5 we observed several associations between MFI of CD25 and MS-associated IL2RA gene variants as well as frequency of $\mathrm{CD} 25^{+}$cells. Our findings indicate that CD25 heterogeneity within $\mathrm{CD}^{+} \mathrm{T}$ cell subgroups are dependent on MS-associated IL2RA gene variants and emphasizes that cell subsets need to be clearly defined by several markers in studies of MS-associated IL2RA gene variants. In $\mathrm{CD}^{+}{ }^{+} \mathrm{T}$ cells, use of too few cell markers for definition of cell subsets can lead to study of mixed effects and lead to inconclusive results.

IL-2 signaling increases with expression of CD25 $[7,8]$ and a previous study by Cerosaletti et al. reported that homozygous carriers of MS-associated IL2RA risk allele for SNP rs2104286 had reduced IL-2 receptor signaling as assessed by STAT5 phosphorylation in CD25 ${ }^{\text {hi }}$ and memory CD4 ${ }^{+} \mathrm{T}$ cells [40]. Thus, these results are consistent with our observation that homozygous carriers of MS-associated IL2RA risk allele rs2104286 and rs11256593 have decreased MFI of CD25 on $\mathrm{T}_{\text {Reg }}$ cells with an EM 
phenotype or $\mathrm{CD} 39^{+}$and $\mathrm{CD} 4^{+} \mathrm{CD} 127^{+} \mathrm{CD} 25^{+} \mathrm{T}$ cell subsets being $\mathrm{CD} 45 \mathrm{RA}^{-/ l o}$ or expressing $\mathrm{CXCR} 3$ and/or CCR6, markers preferentially expressed on memory $\mathrm{CD}^{+} \mathrm{T}$ cells [49]. Cerosaletti et al. did examine if the observed lower STAT5 phosphorylation was due to decreased surface expression of CD25 but contrary to our results found no difference between carriers of the risk and protective allele for SNP rs2104286 [40]. However, Cerosaletti et al. performed stainings on cells from not paired HCs that had undergone a freeze-thaw process while we stained freshly isolated PBMCs from paired HCs. A previous study found that $\mathrm{CD}^{+}$memory cells undergone a freeze-thaw process due to cryopreservation had between $28-62 \%$ lower expression of CD25 compared to CD $4^{+}$memory cells analyzed in fresh whole blood [41] which can explain the discrepancy between the studies. In addition, pairing of the samples as performed in our study reduces day-to-day variation in staining and is more able to identify associations between MS-associated IL2RA gene variants and CD25 expression in cell subsets where cell frequency is age dependent. Finally, the discrepancy between Cerosaletti et al. and our study can be due to difference in cell markers applied to identifying cell subsets and subsequent gating strategy [40].

Analyzing freshly isolated PBMCs limits our study to a steady-state setting and cannot address the extent to which MS-associated IL2RA gene variants rs2104286 and rs11256593 influence T cells IL-2 signaling and effector responses upon activation without compromising our studies ability to identify genotype associations on ex vivo CD25 surface expression and frequency. CD25 expression correlate with T cells responsiveness to IL-2 [7,8], a central cytokine for $\mathrm{T}_{\text {Reg }}$ cells ability to sustain suppressive function and modulates effector responses and T helper lineage commitment [1]. It is a possibility that in a competing immune environment the reduced expression of CD25 in carriers of the IL2RA risk genotype may inhibit the $\mathrm{CD}^{+}{ }^{+} \mathrm{T}$ cells' ability to benefit from the shared pool of IL-2 and as a result promote $C D 4^{+} T$ cells normally inhibited by IL-2 such as $\mathrm{T}_{\mathrm{H}} 17$ and $\mathrm{T}_{\mathrm{FH}}$ cells $[12,13,18,19]$, and inhibit cells normally promoted by IL- 2 such as $\mathrm{T}_{\mathrm{H}} 1$ cells and $\mathrm{T}_{\mathrm{Reg}}$ cells $[1,12,13]$. Furthermore, it is well-established that risk allele carriers of the MS-associated IL2RA SNP rs2104286 have increased concentration of soluble CD25 in sera [42]. Studies have found that soluble CD25 inhibit the action of IL-2 on T cells [39] and may have a functional implication for modulation of T cell responses in MS [60]. In relation to our observation of decreased surface bound CD25, it might be a possibility that carriers of the IL2RA risk genotype have more unstable CD25 that leads to the lower levels of surface bound CD25 and higher levels of soluble CD25 and this exerts a dual effect on IL-2 responsiveness in CD4 ${ }^{+} \mathrm{T}$ cells. As mentioned, the present study is not able to address these questions, however future studies should address how the reduced CD25 expression observed in carriers of the MS-associated IL2RA risk allele affects $\mathrm{CD} 4^{+} \mathrm{T}$ cells IL-2 responsiveness and whether this changes $\mathrm{T}$ helper cells effector functions and $\mathrm{T}_{\text {Reg }}$ cells suppressive capacity and if there is a dual effect with soluble CD25. Interestingly, in carriers of the IL2RA MS-associated risk allele we observed a significant reduction in the frequency of CD25 $5^{+}$ $\mathrm{T}_{\mathrm{FH}} 1$ cells and a suggestive reduction in the frequency of $\mathrm{CD} 25^{+} \mathrm{T}_{\mathrm{H}} 1$ and Th17.1 cells indicating a possible shift in effector functions. Furthermore, such studies could also provide new insight to if and how MS-associated IL2RA SNPs contribute to the impaired suppressive capacity of CD39+ $\mathrm{T}_{\text {Reg }}$ cells [33], the reduced frequency of CXCR5 ${ }^{+} \mathrm{T}_{\mathrm{FH}} 1$ cells [37] and the promotion of pro-inflammatory $\mathrm{CD}^{+} \mathrm{T}$ cells observed in MS patients [31].

In summary, we found that MS-associated IL2RA SNPs rs2104286 and rs11256593 are associated with CD25 expression on $\mathrm{CD} 4^{+}$, but not in $\mathrm{CD} 8^{+} \mathrm{T}$ cells. In $\mathrm{CD} 4^{+} \mathrm{T}$ cells, MS-associated IL2RA gene variants are associated differently within subsets where carriers of the MS-associated risk allele (TT) show decreased surface expression of $\mathrm{CD} 25$ on memory $\mathrm{CD} 127^{+} \mathrm{CD} 25^{+}$and $\mathrm{T}_{\text {Reg }}$ subsets, increased frequency of $\mathrm{CD} 25^{+}$RTE T cells and decreased frequency of $\mathrm{CD} 25^{+} \mathrm{T}_{\mathrm{FH}} 1$ cells. These changes in $\mathrm{CD} 25$ expression may influence the cells IL-2 signaling thus affecting $\mathrm{CD}^{+} \mathrm{T}$ cell differentiation and $\mathrm{T}_{\text {Reg }}$ cells suppressive activity. 
Author Contributions: S.B., H.B.S., A.O., H.U. enrolled healthy subjects and/or collected samples and questionnaire. S.B. performed the experiments. F.S., S.B., H.B.S. and M.R.v.E. conceived and designed the study. S.B., F.S. and H.B.S. wrote the paper. All authors revised and approved the final manuscript.

Funding: This research was supported by the Danish Multiple Sclerosis Society, the Foundation for Research in Neurology, Fonden til Lægevidenskabens Fremme, A.P. Møller og Hustru Chastine Mc-Kinney Møllers Fond til almene Formaal and Novartis Denmark.

Acknowledgments: We wish to thank laboratory technician Lisbeth Egelykke Stolpe for her excellent technical assistance.

Conflicts of Interest: Sophie Buhelt has received support for congress participation from Merck. Helle Bach Søndergaard and Marina Rode von Essen declare no conflict of interest. Annette Oturai has served on scientific advisory boards for Biogen Idec, Novartis and Sanofi Genzyme; has received research support from Novartis and Biogen Idec; has received speaker honoraria from Biogen Idec, Novartis and TEVA; and has received support for congress participation from, Merck, TEVA, Biogen, Roche, Novartis and Sanofi Genzyme. Henrik Ullum has received an unrestricted research grant form Novartis. Finn Sellebjerg has served on scientific advisory boards, been on the steering committees of clinical trials, served as a consultant, received support for congress participation, received speaker honoraria, or received research support for his laboratory from Biogen, EMD Serono, Merck, Novartis, Roche, Sanofi Genzyme and Teva.

\section{References}

1. Boyman, O.; Sprent, J. The role of interleukin-2 during homeostasis and activation of the immune system. Nat. Rev. Immunol. 2012, 12, 180-190. [CrossRef] [PubMed]

2. Malek, T.R.; Castro, I. Interleukin-2 Receptor Signaling: At the Interface between Tolerance and Immunity. Immunity 2010, 33, 153-165. [CrossRef] [PubMed]

3. Kim, H.P.; Imbert, J.; Leonard, W.J. Both integrated and differential regulation of components of the IL-2/IL-2 receptor system. Cytokine Growth Factor Rev. 2006, 17, 349-366. [CrossRef] [PubMed]

4. Lin, J.-X.; Leonard, W.J. Signaling from the IL-2 receptor to the nucleus. Cytokine Growth Factor Rev. 1997, 8, 313-332. [CrossRef]

5. Wang, X.; Rickert, M.; Garcia, K.C. Structure of the quaternary complex of interleukin-2 with its alpha, beta, and gammac receptors. Science 2005, 310, 1159-1163. [CrossRef]

6. Stauber, D.J.; Debler, E.W.; Horton, P.A.; Smith, K.A.; Wilson, I.A. Crystal structure of the IL-2 signaling complex: Paradigm for a heterotrimeric cytokine receptor. Proc. Natl. Acad. Sci. USA 2006, 103, 2788-2793. [CrossRef]

7. Kalia, V.; Sarkar, S.; Subramaniam, S.; Haining, W.N.; Smith, K.A.; Ahmed, R. Prolonged Interleukin-2R $\alpha$ Expression on Virus-Specific CD8+ T Cells Favors Terminal-Effector Differentiation In Vivo. Immunity 2010, 32, 91-103. [CrossRef]

8. Feinerman, O.; Jentsch, G.; Tkach, K.E.; Coward, J.W.; Hathorn, M.M.; Sneddon, M.W.; Emonet, T.; Smith, K.A.; Altan-Bonnet, G. Single-cell quantification of IL-2 response by effector and regulatory T cells reveals critical plasticity in immune response. Mol. Syst. Biol. 2010, 6, 437. [CrossRef]

9. Baecher-Allan, C.; Brown, J.A.; Freeman, G.J.; Hafler, D.A. CD4+CD25high regulatory cells in human peripheral blood. J. Immunol. 2001, 167, 1245-1253. [CrossRef]

10. Kim, H.-P.; Kelly, J.; Leonard, W.J. The Basis for IL-2-Induced IL-2 Receptor $\alpha$ Chain Gene Regulation: Importance of Two Widely Separated IL-2 Response Elements. Immunity 2001, 15, 159-172. [CrossRef]

11. Bielekova, B. Daclizumab therapy for multiple sclerosis. Neurotherapeutics 2013, 10, 55-67. [CrossRef] [PubMed]

12. Liao, W.; Lin, J.-X.; Wang, L.; Li, P.; Leonard, W.J. Modulation of cytokine receptors by IL-2 broadly regulates differentiation into helper T cell lineages. Nat. Immunol. 2011, 12, 551-559. [CrossRef] [PubMed]

13. Laurence, A.; Tato, C.M.; Davidson, T.S.; Kanno, Y.; Chen, Z.; Yao, Z.; Blank, R.B.; Meylan, F.; Siegel, R.; Hennighausen, L.; et al. Interleukin-2 Signaling via STAT5 Constrains T Helper 17 Cell Generation. Immunity 2007, 26, 371-381. [CrossRef] [PubMed]

14. Pepper, M.; Pagán, A.J.; Igyártó, B.Z.; Taylor, J.J.; Jenkins, M.K. Opposing Signals from the Bcl6 Transcription Factor and the Interleukin-2 Receptor Generate T Helper 1 Central and Effector Memory Cells. Immunity 2011, 35, 583-595. [CrossRef] [PubMed] 
15. Hartmann, F.J.; Khademi, M.; Aram, J.; Ammann, S.; Kockum, I.; Constantinescu, C.; Gran, B.; Piehl, F.; Olsson, T.; Codarri, L.; et al. Multiple sclerosis-associated IL2RA polymorphism controls GM-CSF production in human TH cells. Nat. Commun. 2014, 5, 5056. [CrossRef] [PubMed]

16. Chen, Y.; Haines, C.J.; Gutcher, I.; Hochweller, K.; Blumenschein, W.M.; McClanahan, T.; Hämmerling, G.; Li, M.O.; Cua, D.J.; McGeachy, M.J. Foxp3+ Regulatory T Cells Promote T Helper 17 Cell Development In Vivo through Regulation of Interleukin-2. Immunity 2011, 34, 409-421. [CrossRef] [PubMed]

17. Pandiyan, P.; Conti, H.R.; Zheng, L.; Peterson, A.C.; Mathern, D.R.; Hernández-Santos, N.; Edgerton, M.; Gaffen, S.L.; Lenardo, M.J. CD4+CD25+Foxp3+ Regulatory T Cells Promote Th17 Cells In Vitro and Enhance Host Resistance in Mouse Candida albicans Th17 Cell Infection Model. Immunity 2011, 34, 422-434. [CrossRef]

18. Johnston, R.J.; Choi, Y.S.; Diamond, J.A.; Yang, J.A.; Crotty, S. STAT5 is a potent negative regulator of TFH cell differentiation. J. Exp. Med. 2012, 209, 243-250. [CrossRef]

19. Choi, Y.S.; Kageyama, R.; Eto, D.; Escobar, T.C.; Johnston, R.J.; Monticelli, L.; Lao, C.; Crotty, S. ICOS Receptor Instructs T Follicular Helper Cell versus Effector Cell Differentiation via Induction of the Transcriptional Repressor Bcl6. Immunity 2011, 34, 932-946. [CrossRef]

20. Schmitt, N.; Bentebibel, S.-E.; Ueno, H. Phenotype and functions of memory Tfh cells in human blood. Trends Immunol. 2014, 35, 436-442. [CrossRef]

21. Obar, J.J.; Molloy, M.J.; Jellison, E.R.; Stoklasek, T.A.; Zhang, W.; Usherwood, E.J.; Lefrancois, L. CD4+ T cell regulation of CD25 expression controls development of short-lived effector CD8+ T cells in primary and secondary responses. Proc. Natl. Acad. Sci. USA 2010, 107, 193-198. [CrossRef] [PubMed]

22. Pipkin, M.E.; Sacks, J.A.; Cruz-Guilloty, F.; Lichtenheld, M.G.; Bevan, M.J.; Rao, A. Interleukin-2 and Inflammation Induce Distinct Transcriptional Programs that Promote the Differentiation of Effector Cytolytic T Cells. Immunity 2010, 32, 79-90. [CrossRef] [PubMed]

23. Williams, M.A.; Tyznik, A.J.; Bevan, M.J. Interleukin-2 signals during priming are required for secondary expansion of CD8+ memory T cells. Nature 2006, 441, 890-893. [CrossRef] [PubMed]

24. Bachmann, M.F.; Wolint, P.; Walton, S.; Schwarz, K.; Oxenius, A. Differential role of IL-2R signaling for CD8+ $\mathrm{T}$ cell responses in acute and chronic viral infections. Eur. J. Immunol. 2007, 37, 1502-1512. [CrossRef]

25. Castro, I.; Dee, M.J.; Malek, T.R. Transient Enhanced IL-2R Signaling Early during Priming Rapidly Amplifies Development of Functional CD8+ T Effector-Memory Cells. J. Immunol. 2012, 189, 4321-4330. [CrossRef] [PubMed]

26. Lowe, C.E.; Cooper, J.D.; Brusko, T.; Walker, N.M.; Smyth, D.J.; Bailey, R.; Bourget, K.; Plagnol, V.; Field, S.; Atkinson, M.; et al. Large-scale genetic fine mapping and genotype-phenotype associations implicate polymorphism in the IL2RA region in type 1 diabetes. Nat. Genet. 2007, 39, 1074-1082. [CrossRef] [PubMed]

27. Okada, Y.; Wu, D.; Trynka, G.; Raj, T.; Terao, C.; Ikari, K.; Kochi, Y.; Ohmura, K.; Suzuki, A.; Yoshida, S.; et al. Genetics of rheumatoid arthritis contributes to biology and drug discovery. Nature 2014, 506, 376-381. [CrossRef]

28. Beecham, A.H.; Patsopoulos, N.A.; Xifara, D.K.; Davis, M.F.; Kemppinen, A.; Cotsapas, C.; Shah, T.S.; Spencer, C.; Booth, D.; Goris, A.; et al. Analysis of immune-related loci identifies 48 new susceptibility variants for multiple sclerosis. Nat. Genet. 2013, 45, 1353-1360. [CrossRef]

29. International Multiple Sclerosis Genetics Consorti; Patsopoulos, N.; Baranzini, S.E.; Santaniello, A.; Shoostari, P.; Cotsapas, C.; Wong, G.; Beecham, A.H.; James, T.; Replogle, J.; et al. The Multiple Sclerosis Genomic Map: Role of peripheral immune cells and resident microglia in susceptibility. BioRxiv 2017, 143933. [CrossRef]

30. Sawcer, S.; Hellenthal, G.; Pirinen, M.; Spencer, C.C.A.; Patsopoulos, N.A.; Moutsianas, L.; Dilthey, A.; Su, Z.; Freeman, C.; Hunt, S.E.; et al. Genetic risk and a primary role for cell-mediated immune mechanisms in multiple sclerosis. Nature 2011, 476, 214-219. [CrossRef]

31. Nylander, A.; Hafler, D.A. Multiple sclerosis. J. Clin. Investig. 2012, 122, 1180-1188. [CrossRef] [PubMed]

32. Baecher-Allan, C.; Kaskow, B.J.; Weiner, H.L. Multiple Sclerosis: Mechanisms and Immunotherapy. Neuron 2018, 97, 742-768. [CrossRef] [PubMed]

33. Fletcher, J.M.; Lonergan, R.; Costelloe, L.; Kinsella, K.; Moran, B.; O’Farrelly, C.; Tubridy, N.; Mills, K.H.G. CD39+Foxp3+ regulatory T Cells suppress pathogenic Th17 cells and are impaired in multiple sclerosis. J. Immunol. 2009, 183, 7602-7610. [CrossRef] [PubMed]

34. Viglietta, V.; Baecher-Allan, C.; Weiner, H.L.; Hafler, D.A. Loss of functional suppression by CD4+CD25+ regulatory T cells in patients with multiple sclerosis. J. Exp. Med. 2004, 199, 971-979. [CrossRef] [PubMed] 
35. Carbone, F.; De Rosa, V.; Carrieri, P.B.; Montella, S.; Bruzzese, D.; Porcellini, A.; Procaccini, C.; la Cava, A.; Matarese, G. Regulatory T cell proliferative potential is impaired in human autoimmune disease. Nat. Med. 2014, 20, 69-74. [CrossRef]

36. Haas, J.; Fritzsching, B.; Trübswetter, P.; Korporal, M.; Milkova, L.; Fritz, B.; Vobis, D.; Krammer, P.H.; Suri-Payer, E.; Wildemann, B. Prevalence of newly generated naive regulatory T cells (Treg) is critical for Treg suppressive function and determines Treg dysfunction in multiple sclerosis. J. Immunol. 2007, 179, 1322-1330. [CrossRef] [PubMed]

37. Christensen, J.R.; Börnsen, L.; Ratzer, R.; Piehl, F.; Khademi, M.; Olsson, T.; Sørensen, P.S.; Sellebjerg, F. Systemic Inflammation in Progressive Multiple Sclerosis Involves Follicular T-Helper, Th17- and Activated B-Cells and Correlates with Progression. PLoS ONE 2013, 8, e57820. [CrossRef]

38. Salou, M.; Nicol, B.; Garcia, A.; Laplaud, D.-A. Involvement of CD8+ T Cells in Multiple Sclerosis. Front. Immunol. 2015, 6, 604. [CrossRef]

39. Maier, L.M.; Anderson, D.E.; Severson, C.A.; Baecher-Allan, C.; Healy, B.; Liu, D.V.; Wittrup, K.D.; de Jager, P.L.; Hafler, D.A. Soluble IL-2RA levels in multiple sclerosis subjects and the effect of soluble IL-2RA on immune responses. J. Immunol. 2009, 182, 1541-1547. Available online: http://www.jimmunol.org/content/ 182/3/1541.full (accessed on 6 November 2012). [CrossRef]

40. Cerosaletti, K.; Schneider, A.; Schwedhelm, K.; Frank, I.; Tatum, M.; Wei, S.; Whalen, E.; Greenbaum, C.; Kita, M.; Buckner, J.; et al. Multiple autoimmune-associated variants confer decreased IL-2R signaling in CD4+ CD25(hi) T cells of type 1 diabetic and multiple sclerosis patients. PLoS ONE 2013, 8, e83811. [CrossRef]

41. Dendrou, C.A.; Plagnol, V.; Fung, E.; Yang, J.H.M.; Downes, K.; Cooper, J.D.; Nutland, S.; Coleman, G.; Himsworth, M.; Hardy, M.; et al. Cell-specific protein phenotypes for the autoimmune locus IL2RA using a genotype-selectable human bioresource. Nat. Genet. 2009, 41, 1011-1015. [CrossRef] [PubMed]

42. Maier, L.M.; Lowe, C.E.; Cooper, J.; Downes, K.; Anderson, D.E.; Severson, C.; Clark, P.M.; Healy, B.; Walker, N.; Aubin, C.; et al. IL2RA genetic heterogeneity in multiple sclerosis and type 1 diabetes susceptibility and soluble interleukin-2 receptor production. PLoS Genet. 2009, 5, e1000322. [CrossRef] [PubMed]

43. Butter, F.; Davison, L.; Viturawong, T.; Scheibe, M.; Vermeulen, M.; Todd, J.A.; Mann, M. Proteome-Wide Analysis of Disease-Associated SNPs That Show Allele-Specific Transcription Factor Binding. PLoS Genet. 2012, 8, e1002982. [CrossRef] [PubMed]

44. Schwartz, A.M.; Demin, D.E.; Vorontsov, I.E.; Kasyanov, A.S.; Putlyaeva, L.V.; Tatosyan, K.A.; Kulakovskiy, I.V.; Kuprash, D.V. Multiple single nucleotide polymorphisms in the first intron of the IL2RA gene affect transcription factor binding and enhancer activity. Gene 2017, 602, 50-56. [CrossRef] [PubMed]

45. Pedersen, O.B.; Erikstrup, C.; Kotzé, S.R.; Sørensen, E.; Petersen, M.S.; Grau, K.; Ullum, H. The Danish Blood Donor Study: A large, prospective cohort and biobank for medical research. Vox Sang. 2012, 102, 271. [CrossRef] [PubMed]

46. Hedström, A.K.; Hillert, J.; Olsson, T.; Alfredsson, L. Alcohol as a Modifiable Lifestyle Factor Affecting Multiple Sclerosis Risk. JAMA Neurol. 2014, 71, 300. [CrossRef] [PubMed]

47. Buhelt, S.; Ratzer, R.L.; Christensen, J.R.; Börnsen, L.; Sellebjerg, F.; Søndergaard, H.B. Relationship between soluble CD25 and gene expression in healthy individuals and patients with multiple sclerosis. Cytokine 2017, 93, 15-25. [CrossRef] [PubMed]

48. Benjamin, D.J.; Berger, J.O.; Johannesson, M.; Nosek, B.A.; Wagenmakers, E.-J.; Berk, R.; Bollen, K.A.; Brembs, B.; Brown, L.; Camerer, C.; et al. Redefine statistical significance. Nat. Hum. Behav. 2018, 2, 6-10. [CrossRef]

49. Mahnke, Y.D.; Brodie, T.M.; Sallusto, F.; Roederer, M.; Lugli, E. The who's who of T-cell differentiation: Human memory T-cell subsets. Eur. J. Immunol. 2013, 43, 2797-2809. [CrossRef]

50. Seddiki, N.; Santner-Nanan, B.; Martinson, J.; Zaunders, J.; Sasson, S.; Landay, A.; Solomon, M.; Selby, W.; Alexander, S.I.; Nanan, R.; et al. Expression of interleukin (IL)-2 and IL-7 receptors discriminates between human regulatory and activated T cells. J. Exp. Med. 2006, 203, 1693-1700. [CrossRef]

51. Liu, W.; Putnam, A.L.; Xu-Yu, Z.; Szot, G.L.; Lee, M.R.; Zhu, S.; Gottlieb, P.A.; Kapranov, P.; Gingeras, T.R.; Groth, B.F.D.; et al. CD127 expression inversely correlates with FoxP3 and suppressive function of human CD4+ T reg cells. J. Exp. Med. 2006, 203, 1701-1711. [CrossRef] [PubMed] 
52. Kimmig, S.; Przybylski, G.K.; Schmidt, C.A.; Laurisch, K.; Möwes, B.; Radbruch, A.; Thiel, A. Two subsets of naive $\mathrm{T}$ helper cells with distinct $\mathrm{T}$ cell receptor excision circle content in human adult peripheral blood. J. Exp. Med. 2002, 195, 789-794. [CrossRef] [PubMed]

53. Shi, J.; Hou, S.; Fang, Q.; Liu, X.; Liu, X.; Qi, H. PD-1 Controls Follicular T Helper Cell Positioning and Function. Immunity 2018, 49, 264-274.e4. [CrossRef] [PubMed]

54. Morita, R.; Schmitt, N.; Bentebibel, S.-E.; Ranganathan, R.; Bourdery, L.; Zurawski, G.; Foucat, E.; Dullaers, M.; Oh, S.; Sabzghabaei, N.; et al. Human Blood CXCR5+CD4+ T Cells Are Counterparts of T Follicular Cells and Contain Specific Subsets that Differentially Support Antibody Secretion. Immunity 2011, 34, 108-121. [CrossRef] [PubMed]

55. Bonecchi, R.; Bianchi, G.; Bordignon, P.P.; D'Ambrosio, D.; Lang, R.; Borsatti, A.; Sozzani, S.; Allavena, P.; Gray, P.A.; Mantovani, A.; et al. Differential expression of chemokine receptors and chemotactic responsiveness of type 1 T helper cells (Th1s) and Th2s. J. Exp. Med. 1998, 187, 129-134. [CrossRef] [PubMed]

56. Acosta-Rodriguez, E.V.; Rivino, L.; Geginat, J.; Jarrossay, D.; Gattorno, M.; Lanzavecchia, A.; Sallusto, F.; Napolitani, G. Surface phenotype and antigenic specificity of human interleukin 17-producing T helper memory cells. Nat. Immunol. 2007, 8, 639-646. [CrossRef]

57. Paulissen, S.M.J.; Van Hamburg, J.P.; Dankers, W.; Lubberts, E. The role and modulation of CCR6+ Th17 cell populations in rheumatoid arthritis. Cytokine 2015, 74, 43-53. [CrossRef]

58. Singh, S.P.; Zhang, H.H.; Foley, J.F.; Hedrick, M.N.; Farber, J.M. Human T cells that are able to produce IL-17 express the chemokine receptor CCR6. J. Immunol. 2008, 180, 214-221. [CrossRef]

59. Gu, J.; Ni, X.; Pan, X.; Lu, H.; Lu, Y.; Zhao, J.; Zheng, S.G.; Hippen, K.L.; Wang, X.; Lu, L. Human CD39hi regulatory $\mathrm{T}$ cells present stronger stability and function under inflammatory conditions. Cell. Mol. Immunol. 2017, 14, 521-528. [CrossRef]

60. Russell, S.E.; Moore, A.C.; Fallon, P.G.; Walsh, P.T. Soluble IL-2R $\alpha$ (sCD25) exacerbates autoimmunity and enhances the development of Th17 responses in mice. PLoS ONE 2012, 7, e47748. [CrossRef]

(C) 2019 by the authors. Licensee MDPI, Basel, Switzerland. This article is an open access article distributed under the terms and conditions of the Creative Commons Attribution (CC BY) license (http://creativecommons.org/licenses/by/4.0/). 